\title{
35. A COMPARISON OF THE STABLE OXYGEN AND CARBON ISOTOPE COMPOSITION OF EARLY CRETACEOUS AND LATE JURASSIC CARBONATES FROM DSDP SITES 105 AND 367
}

\author{
J.C. Brenneke, ${ }^{1}$ Department of Geology, University of Illinois, Urbana, Illinois
}

\begin{abstract}
Oxygen isotope data indicate that vein-filling carbonates begin to crystallize in approximate isotopic equilibrium with seawater. Pore waters in fracture systems which are partially isolated from seawater become isotopically lighter as the surrounding basalt weathers to clay minerals and zeolites. Vein formation continues at relatively low temperatures in water progressively depleted in $\mathrm{O}^{18}$. Basalts at DSDP Sites 105 and 367 are believed to be extrusive because the sediments immediately overlying them do not have isotopic compositions indicative of high-temperature recrystallization.

Sediments at Site 367 are depleted in $\mathrm{O}^{18}$ relative to those from equivalent units at Site 105. This difference is due to the greater amounts of authigenic carbonate formed at higher temperatures, and possibly in the presence of lighter pore waters, at Site 367 . The differences in isotopic composition and degree of recrystallization between the two sites are attributable to the thicker overburden at Site 367. Significant amounts of $\mathrm{O}^{18}$ must have been incorporated into authigenic silicate phases in order to explain the oxygen isotope composition at Site 367. The lowermost sediments at Site 367 are enriched in $\mathrm{O}^{18}$ relative to the sediments overlying them. Part of this enrichment is due to less recrystallization in these sediments. Oxygen isotope data suggest that recrystallization of these basal carbonates occurred early in the burial history of the sediments.

Nodular chert at Site 367 is associated with carbonates depleted in $\mathrm{O}^{18}$. Present theories of chert formation do not account for this depletion. Clay content also exercises a large effect on the oxygen isotopic composition of carbonates. Carbonate-rich regions are depleted in $\mathrm{O}^{18}$ relative to associated clay-rich zones. This relationship suggests that carbonate-rich regions contain more authigenic carbonate formed at in situ temperatures than do clayrich zones.

The carbon isotopic composition of carbonates from Site 367 varies systematically with depth, reflecting variations in the isotopic composition of dissolved inorganic carbon in the surface ocean. These variations are believed to reflect either changes in the amount of organic matter buried in sediments or changes in the ratio of $\mathrm{C} / \mathrm{P}$ in organisms to that in deep ocean water.
\end{abstract}

\section{INTRODUCTION}

A sequence of Early Cretaceous and Late Jurassic carbonate sediments was penetrated at Site 105, Leg 11, in the western North Atlantic (Hollister et al., 1972). These sediments consist of over 100 meters of Tithonian limestones underlain by 60 meters of clayey limestone and calcareous claystone (Oxfordian to Kimmeridgian age) which rest on basalt at 620 meters subbottom. The Tithonian to Neocomian unit consists of light gray or white limestone interbedded with dark clayey limestone. The dark gray zones are much less lithified than are associated light gray or white layers (Lancelot et al., 1972). The underlying Oxfordian to

\footnotetext{
'Present address: Shell Development Co., P.O. Box 481, Houston, Texas 77001 .
}

Kimmeridgian limestone and claystone are dominantly reddish-brown in color and are frequently interbedded with green zones. These deposits are quite similar to more or less coeval deposits exposed around the Mediterranean Sea (Bernoulli, 1972).

A strikingly similar section was encountered on Leg 41 at Site 367 in the eastern North Atlantic. Here, 250 meters of Early Cretaceous and Late Jurassic limestone overlies basalt at $1145 \mathrm{~m}$ subbottom. These rocks are described in some detail in the site report (Site 367, this volume). A comparison of the lithofacies present at Sites 105 and 367 is discussed at length by Jansa (this volume).

These sedimentary sequences contain similar constituents, and both have been lithified by burial under submarine conditions. The basic difference in the geologic history of the sediments at the two sites consists of the thickness of overburden to which each 
has been subjected. A comparison of the isotopic composition of carbonates from these sites offers an excellent opportunity for studying the effect of temperature and pressure, and associated diagenesis, on the isotopic composition of marine carbonates which have never been exposed to fresh water.

\section{TECHNIQUE}

Dried and ground samples were reacted with $100 \%$ phosphoric acid without further treatment according to standard procedures (McCrea, 1950). The resulting $\mathrm{CO}_{2}$ was purified and analyzed on a dual-collecting, 60sector, Nuclide mass spectrometer. Fractured surfaces of some specimens were mounted on aluminum stubs and coated with gold following 48 hours in a desiccator over osmium tetroxide (Pfefferkorn, 1970). These samples were examined using a Cambridge Mark II scanning electron microscope (SEM).

\section{RESULTS AND DISCUSSION}

The results of the isotopic measurements are given in Table 1. All results except those marked with an asterisk are the averages of duplicate analyses. All data are reported relative to PDB (Craig, 1957). The oxygen isotope results are plotted versus depth in Figures 1 and 2 . The carbon data are similarly plotted in Figures 3 and 4 . The reproducibility of replicate analyses of "clean" carbonate is $\pm 0.1 \%$. The reproducibility for oxygen on some of the samples which contained a relatively low percent carbonate was not as good, generally $\pm 0.2^{\circ} \%$. Reproducibility for carbonate from veins in basalt was very poor. A possible explanation for this is discussed below.

\section{VEIN-FILLING CARBONATES}

The isotopic composition of some carbonate veins in the basalt at Site 105 (Anderson, in preparation) and at Site 367 (this study) are listed in Table 1 and illustrated on Figures 1 through 4. Several veins at Site 105 have oxygen isotope compositions around 0 . These veins must have formed at low temperatures, perhaps $15^{\circ} \mathrm{C}$, or at higher (lower) temperatures in the presence of isotopically heavy (light) water. In these and all other cases discussed in this report, it is not possible to determine the exact temperature of recrystallization from the oxygen isotope data because the isotopic composition of the carbonate depends upon the isotopic composition of the ambient water and the ratio of water to carbonate as well as the temperature. Detail about both these variables is generally lacking. The temperature of bottom water during the Late Cretaceous is estimated to have been $10^{\circ}$ to $15^{\circ} \mathrm{C}$ (Emiliani, 1954; Saito and van Donk, 1975; Savin et al., 1975) and these temperatures may have been characteristic of the Jurassic as well. These veins could easily have been formed at the ocean floor shortly after the basalt cooled, in equilibrium with ocean water at that time. Three of the veins at Site 105 have oxygen isotope compositions of $-4.0^{\circ} \%$ to $-5.0^{\circ} \%$. These values indicate formation at higher temperatures or in equilibrium with isotopically light water.

Anderson and Lawrence (1976) present a model for vein generation from analyses of veins at Site 323. They suggest that initial vein formation occurs at low temperatures in open communication with ocean water. These veins are isotopically heavy. As time progresses, basalt weathers to isotopically heavy clay minerals and zeolites (Muehlenbachs and Clayton, 1972). Pore waters in poor communication with the ocean become isotopically depleted in $\mathrm{O}^{18}$. Later veins crystallize from this isotopically depleted water and are themselves isotopically light. This interpretation suggests that isotopically light veins form much later than isotopically heavy ones, exactly the reverse of an interpretation based on vein generation during cooling. Anderson (in preparation) will discuss the data from Site 105 in more detail with respect to this model, but one additional point in support of the model is worth discussing.

Samples 105-40-1, 104-105 cm (A) and (B) consist of two generations of carbonate. Sample $A$ is fibrous calcite which in thin section can clearly be seen to be replacing the coarsely crystalline B. Sample A is $2.75^{\circ} / 0$ depleted in $\mathrm{O}^{18}$ relative to Sample B. If both calcites formed in equilibrium with water of the same isotopic composition, A would have formed at a higher temperature than B. This is incompatible with the thin section data. The model of Anderson and Lawrence reconciles this inconsistency. The replacement calcite formed in equilibrium with isotopically depleted water and thus lighter than the carbonate it replaced.

All of the veins analyzed from Site 367 have oxygen isotope compositions of $-7.0^{\circ} \% 0$ to $-9.0^{\circ} \%$. These would be in equilibrium with modern ocean water at temperatures on the order of $50^{\circ}$ to $60^{\circ}$.C. Using the interpretations discussed above, these veins formed after considerable weathering of the basalt had occurred. This reasoning suggests that the basalt at Site 367 should be more weathered than the basalt at Site 105 or the fracture system at Site 105 provides more communication with the ocean, and prevents the formation of $\mathrm{O}^{18}$ depleted water.

Replicate analyses of vein carbonate from Site 367 gave very poor agreement (Table 1). The scatter in these values is much greater than analytical precision. The carbonate in these samples was physically separated from the host rock. In many cases, moderately large pieces of carbonate $(0.5$ to $2 \mathrm{~mm}$ in diameter) were obtained. Relatively few pieces of this size are needed to make up a sample for isotope analysis (0.01-0.02 g). If the isotopic composition of the carbonate veins is heterogeneous, then this variability might be expected to show up in replicate analyses. Such isotopic inhomogeneity would occur if vein carbonate initially began to form in equilibrium with normal ocean water and continued to form in equilibrium with progressively lighter water.

\section{Nature of Basalts}

The sediments from Site 105 show no significant trend in oxygen isotope composition with depth. Sediments from Site 367 tend to become more negative with depth down to about 1115 to 1120 meters subbottom. Samples taken between this depth and the underlying basalt are heavier than those immediately above. This data can be used to determine whether the basalts at these sites were intrusive or extrusive. 
TABLE 1

Stable Isotope Composition of Cretaceous and Jurassic Carbonates From Sites 105 and 367

\begin{tabular}{|c|c|c|c|c|c|c|}
\hline $\begin{array}{c}\text { Sample } \\
\text { (Interval } \\
\text { in } \mathrm{cm} \text { ) }\end{array}$ & $\% \mathrm{CaCO}_{3}{ }^{\mathrm{a}}$ & $\delta C^{13}$ & $\delta \mathrm{C}^{18}$ & Depth $(m)^{b}$ & $\mathrm{Age}^{\mathrm{C}}$ & Description \\
\hline $105-17-1,75-7.6$ & 65.9 & +1.76 & -1.32 & 404 & Barr.-Haut. & Dark gray limestone \\
\hline $105-21-1,53-54$ & 50.2 & +2.27 & -1.26 & 449 & Haut.-Val. & Gray-dark gray limestone \\
\hline $105-21-1,62-63$ & 83.1 & +1.47 & -1.82 & 449 & Haut.-Val. & White limestone \\
\hline $105-25-1,15-16$ & 89.4 & +0.90 & -0.78 & 484 & Val.-Tith. & White-gray limestone \\
\hline $105-28-3,53-54$ & 58.4 & +2.02 & -0.98 & 514 & Val.-Tith. & Gray limestone \\
\hline $105-28-3,59-60$ & 64.0 & +1.16 & -1.08 & 514 & Val.-Tith. & Light gray limestone \\
\hline $105-33-1,100-101$ & 88.4 & +1.30 & -2.24 & 559 & Tith.-Kimm. & White limestone \\
\hline $105-33-4,80-81$ & 50.2 & +1.53 & -0.38 & 563 & Tith.-Kimm. & Red, clayey limestone \\
\hline $105-33-4,90-91$ & 50.0 & +1.32 & -0.53 & 563 & Tith.-Kimm. & Reddish tan, clayey limestone \\
\hline $105-35-3,45-46$ & 29.0 & +2.09 & -1.84 & 579 & Kimm.-Oxf. & Red marlstone \\
\hline $105-35-3,50-51$ & 30.8 & +2.24 & -1.58 & 579 & Kimm.-Oxf. & Red marlstone \\
\hline $105-38-2,100-101$ & 27.2 & +1.98 & -0.34 & 605 & Kimm.-Oxf. & Tan-gray-green marlstone \\
\hline $105-38-2,114-115$ & 19.4 & +2.30 & -1.34 & 605 & Kimm.-Oxf. & Red-brown marlstone \\
\hline $105-39-1,100-101^{*}$ & 12.3 & +2.33 & -1.37 & 613 & Kimm.-Oxf. & Red claystone \\
\hline $105-39, \mathrm{CC}^{*}$ & 8.6 & +1.73 & -1.73 & 615 & Kimm.-Oxf. & Red claystone \\
\hline $105-40-1,104-105(\mathrm{~A})^{*}$ & & -1.34 & -4.03 & 621 & & Fibrous calcite \\
\hline $105-40-1,104-105(\mathrm{~B})^{*}$ & & +1.41 & +0.28 & 621 & & Sparry calcite \\
\hline $105-40-1,111-112^{*}$ & & -1.14 & -2.06 & 621 & & Calcite vein \\
\hline $105-40-1,118-119^{*}$ & & -1.80 & -5.36 & 621 & & Calcite pod \\
\hline $105-41-1,118-119 *$ & & -2.04 & +0.63 & 625 & & Calcite vein \\
\hline $105-41-3,45-46^{*}$ & & -1.82 & +0.04 & 626 & & Network of calcite veins \\
\hline $105-41-3,103-104 *$ & & +2.63 & +0.09 & 627 & & Calcite vein \\
\hline $105-42-2,81(\mathrm{~A})^{*}$ & & +2.47 & +0.39 & 629 & & Clay-rich carbonate rock \\
\hline $105-42-2,81(\mathrm{~B})^{*}$ & & +2.88 & +0.16 & 629 & & Calcite vein \\
\hline $105-42-2,129^{*}$ & & +1.54 & -4.18 & 630 & & Coarse crystalline calcite \\
\hline $105-43-1,102-103^{*}$ & & +1.96 & -0.59 & 631 & & Calcite vein \\
\hline $367-25-1,9-10$ & 83.2 & +0.62 & -4.10 & 892 & Neocomian & Hard gray limestone \\
\hline $367-25-1,14-15$ & 31.0 & +2.04 & -3.58 & 892 & Neocomian & Dark gray marlstone \\
\hline $367-25-3,59-61(\mathrm{~L})$ & 79.0 & +0.82 & -3.55 & 895 & Neocomian & Light gray limestone \\
\hline $367-25-3,59-61$ (D) & 53.2 & +1.26 & -2.46 & 895 & Neocomian & Dark gray marlstone \\
\hline $367-26-1,50-51$ & 89.5 & +1.05 & -3.81 & 911 & Apt.-Barr. & Hard white limestone \\
\hline $367-26-1,67-69$ (GC) & 55.0 & +1.40 & -2.88 & 911 & Apt.-Barr. & Gray limestone \\
\hline $367-26-1,67-69$ (WC) & 77.9 & +1.09 & -3.84 & 911 & Apt.-Barr. & White limestone \\
\hline $367-27-2,130-131$ & 87.2 & +1.39 & -3.72 & 942 & Neocomian & Hard white limestone \\
\hline $367-27-2,137-139(W)$ & 77.8 & +1.34 & -3.84 & 942 & Neocomian & White limestone \\
\hline $367-27-2,137-139(\mathrm{G})$ & 41.6 & +1.96 & -2.26 & 942 & Neocomian & Gray clayey limestone \\
\hline $367-27-3,50-51$ & 92.0 & +1.42 & -4.71 & 942 & Neocomian & White limestone \\
\hline $367-28-1,113-114$ & 77.8 & +1.98 & -3.22 & 969 & Neoc.-Val. & Gray clayey limestone \\
\hline $367-28-1,134-136$ & 91.3 & +1.86 & -3.74 & 969 & Neoc.-Val. & Hard white limestone \\
\hline $367-28-3,69-71$ & 68.5 & +2.38 & -3.06 & 971 & Neoc.-Val. & Dark gray marlstone \\
\hline $367-28-3,108-109$ & 89.2 & +1.81 & -5.18 & 972 & Neoc.-Val. & Hard whitish limestone \\
\hline $367-29-1,109-111$ (UC)* & 76.1 & +2.56 & -6.11 & 997 & Berr.-Haut. & Chalk above chert \\
\hline $367-29-1,109-111$ (LC) & 92.1 & +2.60 & -4.96 & 997 & Berr.-Haut. & Chalk below chert \\
\hline $367-29-1,137-139$ & 94.6 & +2.67 & -5.00 & 997 & Berr.-Haut. & Hard whitish limestone \\
\hline $367-30-1,59-60$ & 88.3 & +1.96 & -3.78 & 1026 & Tithonian & White limestone \\
\hline $367-30-1,72-73$ & 51.8 & +2.17 & -3.32 & 1025 & Tithonian & Black marlstone \\
\hline $367-30-1,87$ & 83.8 & +1.98 & -4.65 & 1025 & Tithonian & Hard whitish limestone \\
\hline $367-30-1,112-113$ & 69.4 & +1.95 & -4.58 & 1026 & Tithonian & Gray marlstone \\
\hline $367-30-1,137-138$ & 76.1 & +1.96 & -3.35 & 1026 & Tithonian & Hard whitish limestone \\
\hline $367-30-297-99$ & 89.0 & +1.38 & -4.31 & 1027 & Tithonian & Hard whitish limestone \\
\hline $367-30-1,139-140$ & 93.4 & +1.23 & -5.31 & 1027 & Tithonian & "Salt and pepper" limestone \\
\hline $376-31-1,65-67(\mathrm{C} 1)$ & 79.2 & +1.30 & -6.42 & 1054 & Tithonian & Chalk above chert \\
\hline $367-31-1,65-67(\mathrm{C} 2)$ & 23.2 & +0.91 & -7.98 & 1054 & Tithonian & Chalk below chert \\
\hline $367-32-3,86-87$ (WC1) & 76.3 & +1.22 & -4.34 & 1085 & Kimm. (+) & White limestone \\
\hline $367-32-3,86-87$ (GC1) & 23.8 & +1.27 & -3.28 & 1085 & Kimm. (+) & Green-gray marlstone \\
\hline $367-32-3,86-87$ (WC2) & 79.9 & +1.37 & -4.40 & 1085 & Kimm. (+) & White limestone \\
\hline $367-32-3,86-87$ (GC2) & 37.8 & +1.29 & -3.90 & 1085 & Kimm. (+) & Green-gray marlstone \\
\hline $367-32-3,135-136$ & 55.8 & +1.30 & -4.88 & 1086 & Kimm. (+) & Hard white limestone \\
\hline $367-32-5,50-51$ & 85.8 & +1.42 & -5.72 & 1088 & Kimm. (+) & Hard white limestone \\
\hline $367-32-5,55-56$ & 50.6 & +1.41 & -5.16 & 1088 & Kimm. (+) & Hard pinkish limestone \\
\hline $367-32-5,135-136$ & 48.0 & +1.44 & -1.84 & 1089 & Kimm. (+) & Red-brown marlstone \\
\hline $367-33-2,67-69$ & 83.8 & +1.48 & -3.45 & 1108 & Kimm. (+) & Pink limestone \\
\hline $367-33-2,75-77$ & 37.8 & +1.42 & -3.05 & 1108 & Kimm. (+) & Red-brown marlstone \\
\hline $367-33-3,80-81$ & 90.4 & +1.03 & -5.56 & 1109 & Kimm. (+) & Hard white limestone \\
\hline $367-34-1,105-106$ & 18.4 & +1.27 & -2.70 & 1112 & Kimm. (+) & Greenish claystone \\
\hline $367-34-1,107-109$ & 92.8 & +1.63 & -5.67 & 1112 & Kimm. (+) & Hard white limestone \\
\hline $367-34-1,137-139$ & 90.0 & +1.65 & -4.72 & 1112 & Kimm. (+) & Hard white limestone \\
\hline
\end{tabular}


TABLE 1 - Continued

\begin{tabular}{|c|c|c|c|c|c|c|}
\hline $\begin{array}{l}\text { Sample } \\
\text { (Interval } \\
\text { in } \mathrm{cm} \text { ) }\end{array}$ & $\% \mathrm{CaCO}_{3}{ }^{\mathrm{a}}$ & $\delta \mathrm{C}^{13}$ & $8 C^{18}$ & Depth $(m)^{b}$ & $\mathrm{Age}^{\mathrm{C}}$ & Description \\
\hline $367-34-3,104-105(W)$ & 86.8 & +1.70 & -4.28 & 1115 & Kimm. (+) & White limestone \\
\hline $367-34-3,104-105(\mathrm{R})$ & 20.2 & +1.54 & -2.45 & 1115 & Kimm. (+) & Red-brown claystone \\
\hline $367-34-4,20-23(W)$ & 35.2 & +1.55 & -6.42 & 1116 & Kimm. (+) & White chalk \\
\hline $367-34-4,20-23(\mathrm{G})$ & 11.5 & +1.62 & -3.23 & 1116 & Kimm. $(+)$ & Green claystone \\
\hline $367-34-420-23(\mathrm{R})$ & 19.8 & +1.60 & -3.74 & 1116 & Kimm. $(+)$ & Red claystone \\
\hline $367-34-4,124-125$ & 48.8 & +2.00 & -1.77 & 1117 & Kimm. $(+)$ & Red marlstone \\
\hline $367-35-4,51-53$ & 6.4 & +1.62 & -2.13 & 1125 & Kimm. (+) & Green-gray claystone \\
\hline $367-35-4,61-63$ & 88.1 & +2.07 & -4.16 & 1125 & Kimm. (+) & Hard white limestone \\
\hline $367-35-4,101-102$ (DG) & 15.4 & +1.62 & -1.62 & 1125 & Kimm. $(+)$ & Dark gray claystone \\
\hline $367-35-4,101-102$ (B) & 17.2 & +1.54 & -1.64 & 1125 & Kimm. (+) & Brown claystone \\
\hline $367-35-4,101-102(\mathrm{~W})^{*}$ & 16.7 & +169 & -2.87 & 1125 & Kimm. (+) & Gray-white claystone \\
\hline $367-36-3,23-25(G)$ & 61.2 & +2.26 & -2.42 & 1131 & Kimm. $(+)$ & Gray-white limestone \\
\hline $367-36-3,23-25(\mathrm{P})$ & 45.5 & +2.36 & -2.16 & 1131 & Kimm. (+) & Pinkish marlstone \\
\hline $367-37-1,67-69$ & 44.6 & +2.60 & -1.98 & 1136 & Kimm. $(+)$ & Reddish marlstone \\
\hline $367-38-1,143-144$ & 33.4 & +2.28 & -2.50 & 1143 & Kimm. $(+)$ & Greenish-gray marlstone \\
\hline $367-38-1,148-149$ & 59.5 & +2.40 & -2.33 & 1144 & Kimm. $(+)$ & Greenish limestone \\
\hline $367-38-2,9-10(\mathrm{R})$ & 22.0 & +2.29 & -2.18 & 1144 & Kimm. $(+)$ & Reddish marlstone \\
\hline $367-38-2,9-10(\mathrm{G})$ & 40.8 & +2.33 & -1.68 & 1144 & Kimm. (+) & Greenish marlstone \\
\hline $367-38-2,35-36$ & 54.6 & +2.16 & -3.80 & 1144 & Kimm. (+) & Greenish limestone \\
\hline $367-38-2,14 *$ & & $\begin{array}{l}+2.39 \\
+2.30\end{array}$ & $\begin{array}{l}-7.74 \\
-7.98\end{array}$ & 1144 & & Calcite vein \\
\hline \multirow[t]{3}{*}{$367-38-3,34 *$} & & -0.99 & -6.34 & 1145 & & Calcite vein \\
\hline & & +0.56 & -9.58 & & & \\
\hline & & +1.68 & -7.62 & & & \\
\hline $367-38-3,110-111^{*}$ & & $\begin{array}{l}+1.94 \\
+1.17\end{array}$ & -7.38 & 1146 & & Calcite vein \\
\hline \multirow[t]{2}{*}{$367-39-1,57-59^{*}$} & & $\begin{array}{l}+1.17 \\
+1.90\end{array}$ & $\begin{array}{l}-6.45 \\
-6.83\end{array}$ & 1149 & & Calcite vein \\
\hline & & +1.58 & -7.35 & & & \\
\hline \multirow[t]{2}{*}{$367-39-2,49-50 *$} & & +2.20 & -6.94 & 1150 & & Calcite vein \\
\hline & & +2.00 & -7.18 & & & \\
\hline \multirow[t]{2}{*}{$367-40-1,104 *$} & & +2.33 & -6.16 & 1152 & & Calcite vein \\
\hline & & +1.21 & -8.22 & & & \\
\hline
\end{tabular}

${ }^{a}$ Based on the amount of carbon dioxide liberated by acidification.

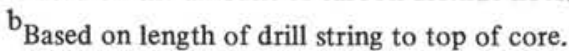

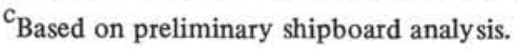

Note: * - see text for explanation. All isotope data relative to PDB. Data for Site 105, Cores 40-43 from Anderson (in preparation).

Drilling in the Caribbean on Leg 15 encountered carbonate sediments overlying a dolerite sill (Edgar et al., 1973). The heat from the sill must have produced a very high geothermal gradient in the overlying sediment. This submarine igneous activity stimulated the recrystallization and lithification of the overlying carbonates (Anderson and Schneidermann, 1973). Recrystallization at higher than normal temperatures produced a shift of several per mil in the oxygen isotopic composition of the sediments toward more negative values (Anderson and Schneidermann, 1973). This isotopic shift is observed for over 200 meters in the limestones above the sill.

The lack of any such shift in the sediments immediately overlying the basalt at Sites 105 and 367 strongly suggests that the basalts in these cases are extrusive or intruded a very thin sediment pile. Moore et al. (1973) show that basalt flowing into the sea raises the temperature of the surrounding water only $3^{\circ} \mathrm{C}$ due to the efficient convective transfer of heat. A thin sediment veneer would only slightly restrict this transfer and temperatures would be only slightly higher. Studies by Garrison et al. (1973) show that thin layers of sediment trapped within basalt pillows record little isotopic evidence of high temperature recrystallization. A thick sediment pile slows down convective heat transfer and permits elevated temperatures to build up. This was not the situation at either Sites 105 or 367.

\section{OVERALL OXYGEN ISOTOPIC TRENDS}

Comparison of Figures 1 and 2 reveals that the oxygen isotopic composition of sediments from both units at Site 367 are more negative than sediments from the corresponding unit at Site 105 . It seems unlikely that these sediments differed greatly in initial composition. If so, the differences seen now are due to differences in the degree of recrystallization, the temperature of recrystallization, the isotopic composition of the pore waters, the ratio of water to carbonate, or some combination of these factors. Lawrence et al. (1975) show that the weathering of the basaltic basement to authigenic clays or zeolites can produce pore waters depleted in $\mathrm{O}^{18}$ in the overlying sediments. Brenneke and Anderson (1975) suggest that this effect can be reflected in the sediments in the form of a slight negative shift in the oxygen isotopic composition. This is obviously not the case at Site 367 


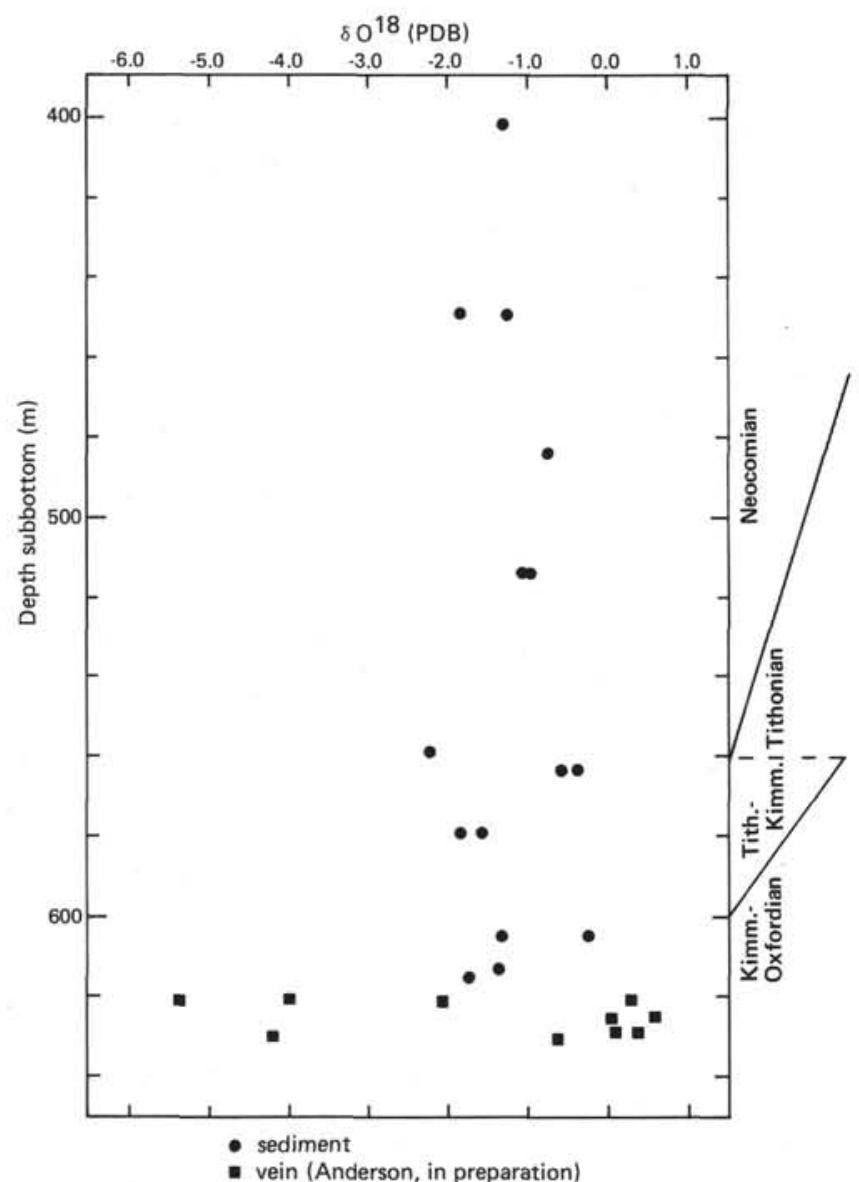

Figure 1. Oxygen isotope composition of Cretaceous and Jurassic carbonates from Site 105.

where the sediments immediately above the basalt are much heavier than those overlying them.

Perry et al. (1976) demonstrated that the alteration of volcanic debris to authigenic silicates can produce a similar effect on the pore water composition. Eade and Anderson (1975) and Anderson and Lawrence (1976) demonstrate that this can result in isotopically light carbonates. The difference in the oxygen isotopic composition between Sites 105 and 367 could be due to a greater amount of authigenic silicates at Site 367. Although simpler explanations for the isotope data are available, this possibility deserves to be examined in more detail.

Jansa et al. (this volume) shows that the sediments at Site 367 are more highly recrystallized than those at Site 105 . This conclusion is confirmed by scanning electron microscopy done in conjunction with this study. Sediments from Site 105 contain a much higher percentage of recognizable nannofossil debris than do sediments from Site 367 (Plate 1). Oxygen isotope values are frequently $-3 \%$ oo to $-4^{\circ} \%$ in sediments above 1120 meters subbottom at Site 367 . Shackleton and Kennett (1975a) estimate that the isotopic composition of the ocean prior to the formation of continental ice sheets was $-0.9^{\circ} \%$ relative to the present ocean. This may have also been the initial composition of pore waters in oceanic sediments deposited prior to the formation of extensive continental ice masses. The

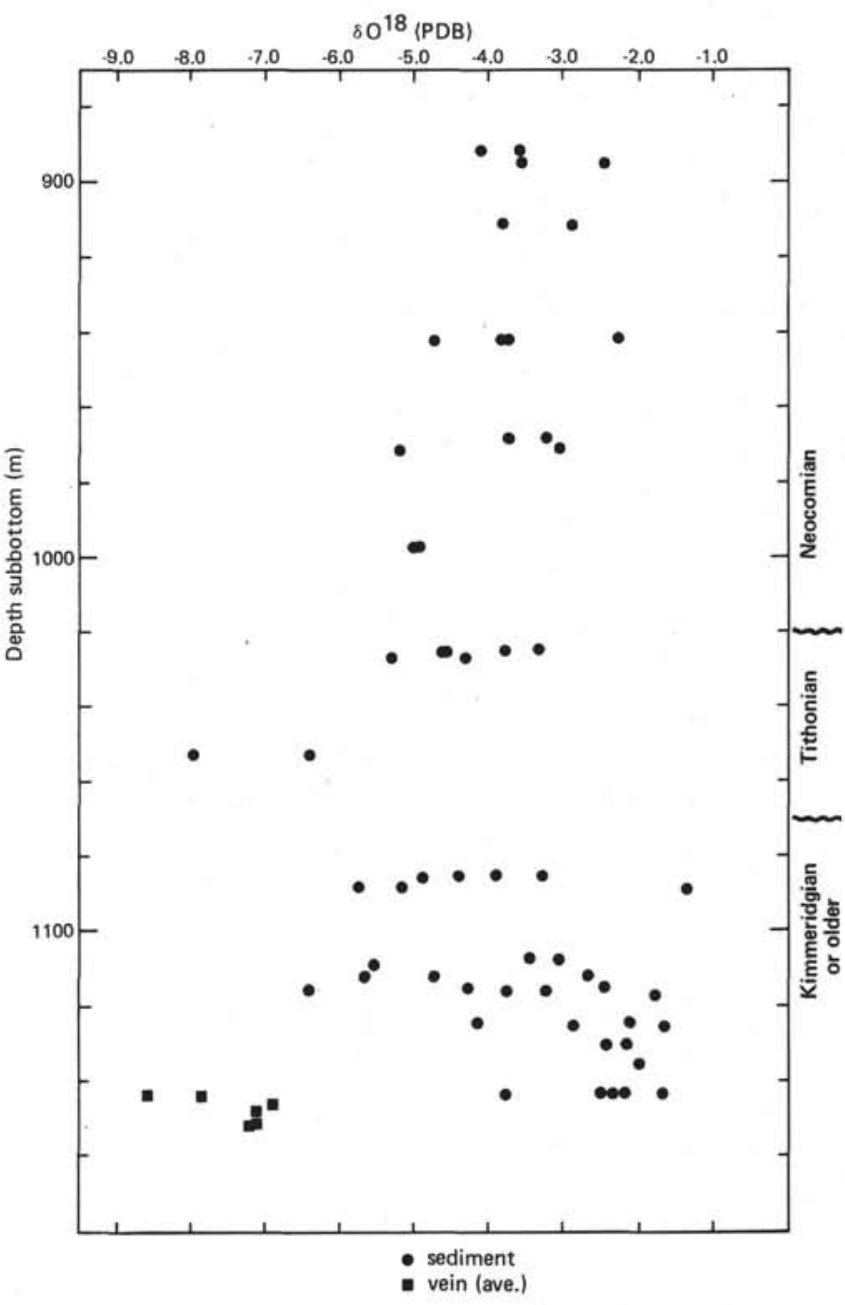

Figure 2. Oxygen isotope composition of Cretaceous and Jurassic carbonates from Site 367.

sediments at Site 367 would have been in equilibrium with pore water of that composition at $27^{\circ}$ to $32^{\circ} \mathrm{C}$ (Craig, 1965). Assuming a geothermal gradient of $4^{\circ} \mathrm{C} / 100 \mathrm{~m}$ and a modern-day bottom temperature of $2^{\circ} \mathrm{C}$, this corresponds to burial depths of 650 to 750 meters, slightly less than present-day burial depths. SEM examination of these sediments shows that they consist of a mixture of original material and authigenic carbonate. The isotopic composition observed is the product of a mixture of carbonate which crystallized at in situ temperatures and carbonate which formed at lower temperatures.

With the exception of Samples 367-29-1, 109-111 cm (UC), $367-31-3,65-67 \mathrm{~cm}$, and $367-34-4,20-23 \mathrm{~cm}$, (WC1) and (WC2) (discussed separately below), the most negative value obtained for the sediment was $-5.7 \%$ for Sample $367-32-5,50-51 \mathrm{~cm}$. This corresponds to an equilibrium temperature of $45^{\circ} \mathrm{C}$ or a burial depth of about 1100 meters. This sample must have undergone essentially total recrystallization at, or very near, the present depth of burial or in the presence of isotopically light pore waters. These calculations assume that the ratio of oxygen in the pore water to oxygen in the carbonate is very large so that the isotopic composition of the pore water does not change 


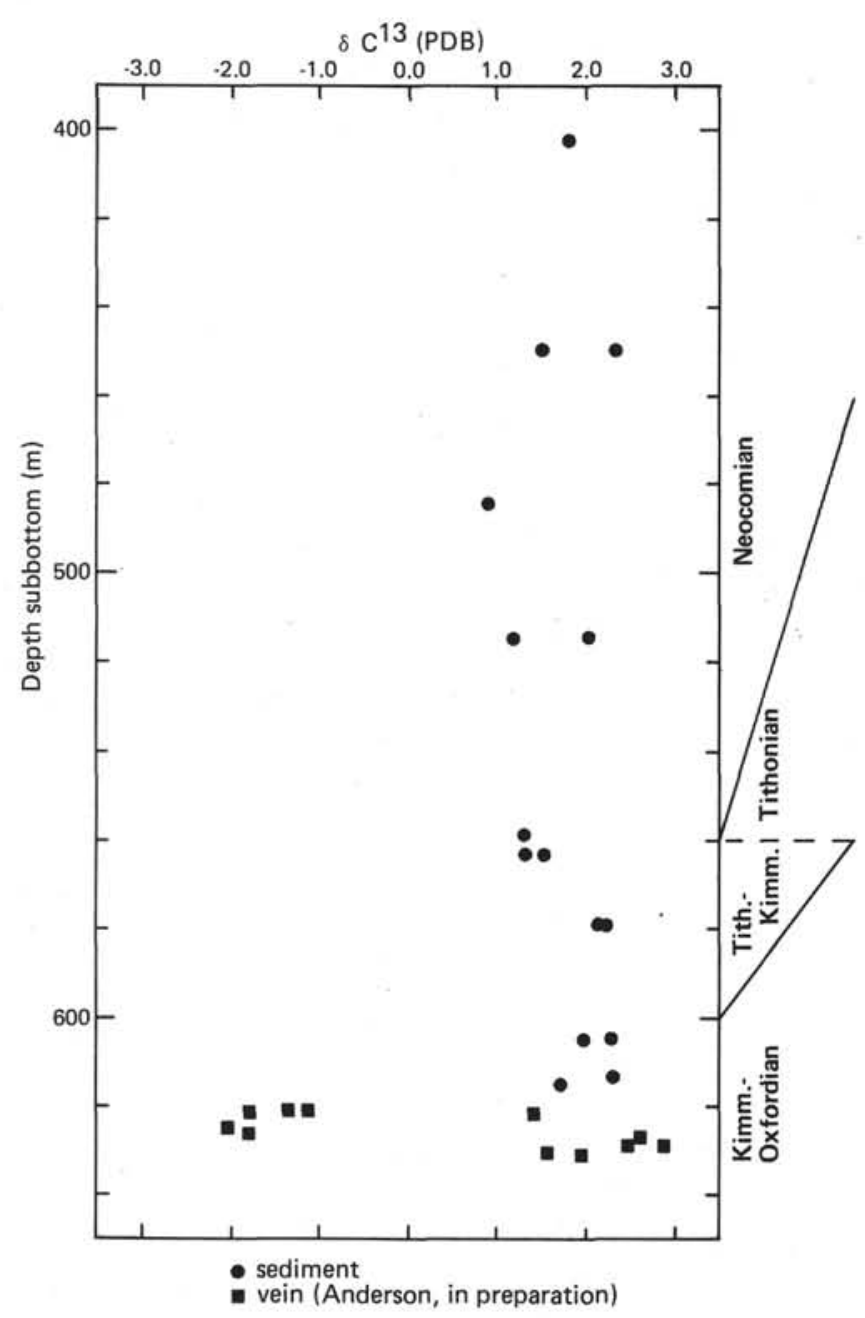

Figure 3. Carbon isotope composition of Cretaceous and Jurassic carbonates from Site 105.

significantly as it exchanges oxygen with the carbonate. Assuming a porosity of $40 \%$, this ratio is only about 0.5 , far smaller than required. In order to produce carbonate of the observed composition, the system must have been open to the flow of pore water or a source of $\mathrm{O}^{18}$ depleted water must have been available. The flux of pore water cannot be solely from compaction because water forced up through the sediment would have already exchanged oxygen with the underlying carbonate. Geochemical measurements on pore waters in the upper portions of other drill holes (Sayles and Manheim, 1974, and references therein) show no sign of ocean water percolation downward into the sediment column. Measurements of the isotopic composition of pore waters (see references below) also show no evidence of downward movement of water.

As discussed above, the isotopic composition of pore waters decreases due to the formation of authigenic silicates from volcanogenic precursors. Isotopic gradients of between 0 and $-1 \%$ oo/ $100 \mathrm{~m}$ for calcareous sediments (Lawrence, 1973, 1974; Lawrence et al., 1975; Perry et al., 1976) and up to -3 and $-4 \% 00 / 100 \mathrm{~m}$ for dominantly siliceous sediments (Gieskes and Lawrence, 1976) have been measured. The isotopic composition of

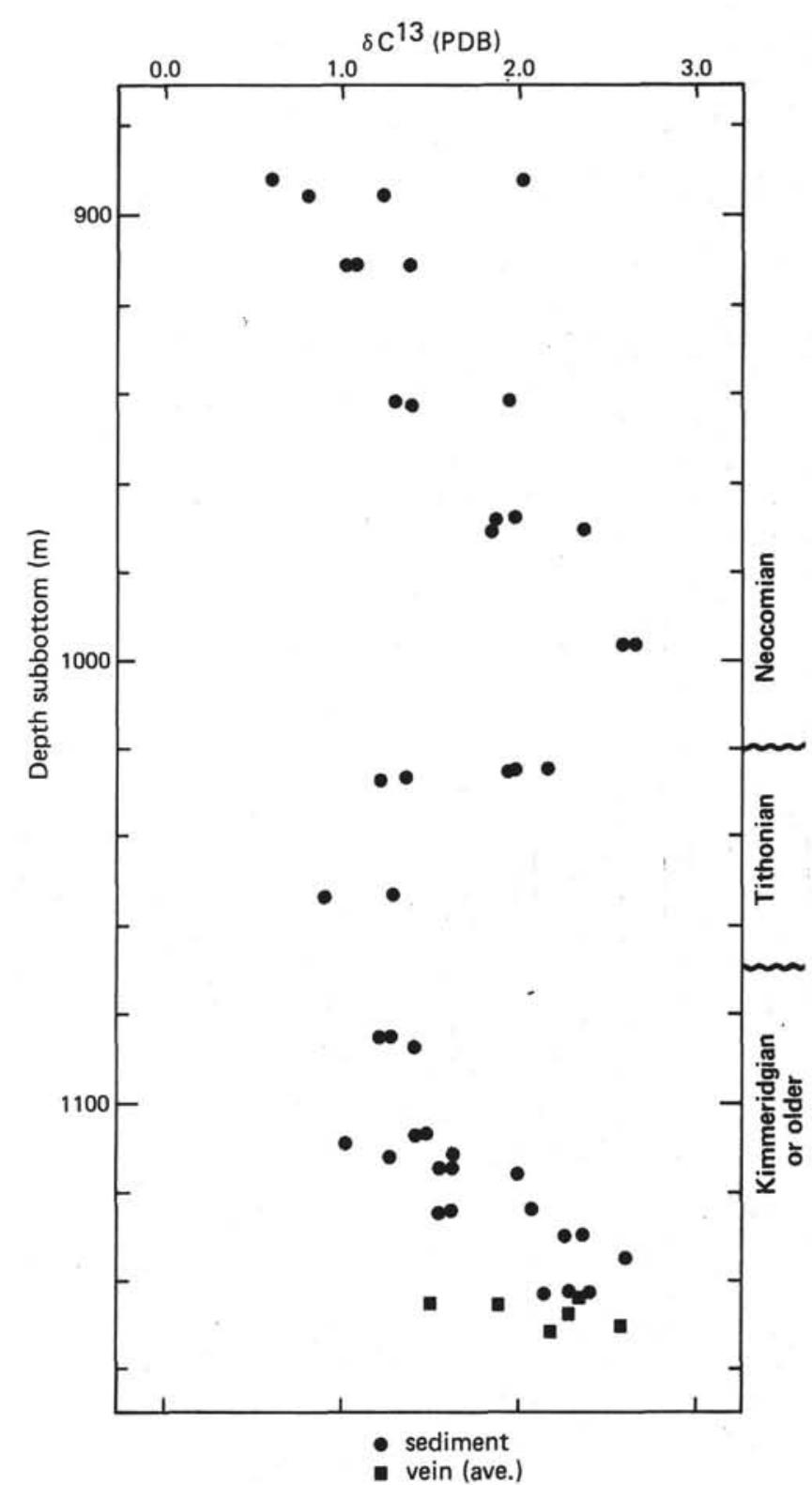

Figure 4. Carbon isotope composition of Cretaceous and Jurassic carbonates from Site 367.

the pore waters is sensitive to the ratio of authigenic silicate to authigenic carbonate and the depth at which the authigenic phases form. None of this information is available for these two sites.

The alteration of volcanogenic material to authigenic minerals takes up $\mathrm{Mg}^{++}$and releases $\mathrm{Ca}^{++}$as well as depleting the water in $\mathrm{O}^{18}$ (Lawrence et al., 1975; Perry et al., 1976; Gieskes and Lawrence, 1976). In all cases where significant isotopic gradients have been found in the pore waters, they have been accompanied by substantial increases in the $\mathrm{Ca}^{++}$concentration and decreases in the $\mathrm{Mg}^{++}$concentration of the pore water. These characteristic changes in $\mathrm{Ca}^{++}$and $\mathrm{Mg}^{++}$ concentrations have never been observed at sites where measurement failed to reveal a depletion in the $\mathrm{O}^{18}$ content of the pore waters. In the upper 325 meters at Site 105 , the $\mathrm{Ca}^{++}$concentration doubles, but the $\mathrm{Mg}^{++}$ concentration shows little change (Sayles et al., 1972). 
At Site 367 the $\mathrm{Ca}^{++}$concentration increases from about 10 mmoles/1near the top of the sediment column to about 50 mmoles/ 1 at 8000 meters subbottom. $\mathrm{Mg}^{++}$ concentrations show a much smaller change from slightly over $50 \mathrm{mmoles} / 1$ near the sediment-water interface to about $40 \mathrm{mmoles} / 1$ at 800 meters. The relation of these data to the pore water composition at much deeper depths is not clear, but the data above suggest that the pore waters at Site 367 are likely to be more depleted in $\mathrm{O}^{18}$ than the waters at Site 105.

As mentioned previously, bottom-water temperatures in the early Tertiary may have been $10^{\circ} \mathrm{C}$ higher than they are today. At the end of the Cretaceous, the sediment thickness at Site 367 amounted to at least about 600 meters (site report, this volume). Temperatures near the base of the sediment column were probably at least $35^{\circ} \mathrm{C}$. Since the end of the Cretaceous, carbonate sediments at Site 367 have been exposed to conditions which could produce their approximate present isotopic compositions.

Sediment thickness at Site 105 at the end of the Cretaceous was about 350 meters (site report, Hollister et al., 1972). In situ temperature in the basal sediments should have been near $25^{\circ} \mathrm{C}$, the same as today. Carbonate formed in equilibrium with these conditions (assuming a isotopic composition for pore water) would have an $\mathrm{O}^{18}$ value of about $-3 \%$. This is slightly lighter than the lightest sample (105-33-1, 100-101 cm) analyzed from this hole, which is not totally recrystallized (Plate 1, Figures 3 and 4). Even the lightest sample at Site 105 could be produced without the presence of $\mathrm{O}^{18}$ depleted pore water. Such pore water may have existed at this site, but the isotope evidence for its existence is lacking.

\section{LOWERMOST SEDIMENTS AT SITE 367}

Scholle (1976) presents data which suggest that lithification and recrystallization in deep-sea chalks and limestones is primarily due to pressure solution. An example of this phenomenon is illustrated in Plate 2, Figure 6. Pressure solution is driven by the change in solubility associated with the difference between the confining pressure of the pore fluid and and the pressure at grain-to-grain contacts. Pressure solution would be expected to proceed faster at the greater pressure differentials in the more deeply buried sediments at Site 367. (Only the thickness of overlying sediment needs to be considered here as the weight of overlying water contributes equally to confining pressure and pressure at grain-to-grain contacts.) The higher temperatures associated with a greater sediment thickness may also be significant. Owen and Brinkley (1941) conclude that an increase in temperature decreases the effect of pressure on the solubility of weak electrolytes, but the increase in the rate of chemical reactions associated with higher temperatures may offset this. Perhaps more significantly, higher temperatures increase the rate of diffusion of ions. Weyl (1959) suggests that the rate limiting step in pressure solution is the diffusion of ions away from the point of grain contact in a thin film of water which is present between the grains. If Weyl's postulated mechanism is true, then the increased rate of diffusion at the higher temperatures experienced at Site 367 should be significant.

In light of the above analysis, the isotopic data from the lowermost sediments at Site 367 (below $1120 \mathrm{~m}$ subbottom) are difficult to interpret. These sediments should be the most highly recrystallized and, correspondingly, have the most negative $\mathrm{O}^{18}$ values of any sediments analyzed, yet they are significantly heavier isotopically than the sediments immediately above (Figure 2). The isotopic data suggest that these lowermost sediments must be significantly less recrystallized than the overlying samples or they must have recrystallized at lower temperatures and therefore with a thinner overburden. Most probably the answer is a combination of the two factors. Jansa (this volume) reports that the occasional nannofossils in these lowermost sediments are well preserved although the matrix of the rock is a dense neomorphic calcite. Recrystallization in the lower sediments is clearly extensive enough that much of it had to occur at lower temperatures early in the burial history of the sediments.

\section{EFFECT OF CHERT FORMATION}

Samples 367-31-1, 65-67 cm (C1) and (C2) are from just above and below a small chert nodule. Sample $\mathrm{Cl}$ is from between 5 and $10 \mathrm{~mm}$ above the chert whereas Sample C2 is closer, perhaps $2 \mathrm{~mm}$ away. These two samples have the most negative oxygen isotopic compositions of any sediments analyzed from Site 367 . Sample C2 $\left(-8.0^{\circ} \% 0\right)$ would be in equilibrium with ocean water at a temperature of about $60^{\circ} \mathrm{C}$. This would require a geothermal gradient of $6^{\circ} \mathrm{C} / 100 \mathrm{~m}$. Such a geothermal gradient would require an unreasonably high heat flow for crust of Jurassic age (heat flow data from Sclater and Francheteau, 1970; thermal conductivity data from Langseth, 1965, and Von Herzen et al., 1971). Even Sample C1 $\left(-6.4^{\circ} \% 00\right)$ would require a geothermal gradient of $5^{\circ} \mathrm{C} / 100 \mathrm{~m}$. This suggests that recrystallization of these samples took place in the presence of water significantly depleted in $\mathrm{O}^{18}$ relative to ocean water.

The $\mathrm{O}^{18}$ depleted pore water apparently existed only around the chert nodule or recrystallization was concentrated there because this effect is evident only locally. Sample C2, which is from closer to the chert nodule and contains more silica itself, is isotopically lighter than $\mathrm{Cl}$. Water depleted in $\mathrm{O}^{18}$ would have formed if an authigenic phase rich in $\mathrm{O}^{18}$ formed from a precursor which was depleted in $\mathrm{O}^{18}$. Heath and Moberly (1971), Heath (1973), and Wise and Weaver (1974) argue strongly that nodular chert forms by remobilization of biogenic silica. Biogenic silica ranges in oxygen isotope composition from $+2.4^{0} \%$ to $+6.3^{\circ} \%$ (Mopper and Garlick, 1971; Knauth and Epstein, 1975). Deep-sea cherts range in composition from $+0.5^{\circ} \%$ to $+6.0^{\circ} \%$ (Knauth and Epstein, 1975). At temperatures of $30^{\circ} \mathrm{C}$ and above, chert formed from a biogenic precursor enriches pore water in $\mathrm{O}^{18}$ rather than depletes it (Lawrence et al., 1975). Even at temperatures below $10^{\circ} \mathrm{C}$, the $\mathrm{O}^{18}$ depletion of pore waters caused by this type of chert formation is very small (Lawrence et al., 1975). 
Knauth and Epstein (1975) present data suggesting that opal-CT (the first step in chert formation) forms during shallow burial (less than $100 \mathrm{~m}$ depth). Opal-CT replaces the calcite matrix, releasing calcium carbonate which reprecipitates in the surrounding carbonate ooze (Wise and Weaver, 1974). Authigenic carbonate formed at this temperature (very shallow burial) should be relatively heavy, even if the pore water was somewhat depleted in $0^{18}$ due to chert formation. The final step in chert formation is the inversion of opal-CT (disordered cristobalite) to microcrystalline quartz (Heath and Moberly, 1971; Wise and Weaver, 1974). This step normally takes place at elevated temperatures, either due to deep burial or a very high geothermal gradient (Heath and Moberly, 1971). Lancelot (1973) and Keene (1975) suggest that some quartz may form directly, without the opal-CT precursor. Knauth and Epstein (1975) report that microcrystalline quartz is depleted in $0^{18}$ rleative to co-existing opal-CT. Thus either the transition from opal-CT to quartz or the direct precipitation of quartz would enrich pore waters in $0^{18}$ rather than deplete them.

If all of the above assumptions regarding the geothermal gradient, mode of chert formation, and isotopic composition of deep-sea chert and its precursors are correct, then the oxygen isotope data from Samples 367-31-1, 65-67 cm (C1) and (C2) are inexplicable. It is tempting to suggest that this chert nodule formed from a volcanic precursor. Volcanic ash typically has an oxygen isotope composition of about $-23^{\circ} \%$ relative to PDB $\left(+8^{\circ} \%\right.$ SMOW, Garlick and Dymond, 1970). Formation of chert with an isotopic composition of $+3 \%$ would produce pore waters immediately adjacent to the nodule which are greatly depleted in $0^{18}$. Such an explanation would not have to be universal because Knauth and Epstein found no such unusual values in carbonates associated with the cherts they analyzed, although the same effect appears present in Sample 367-29-1, 109-111. Unfortunately petrographic and SEM examination of 367-31-1, 65-67 $\mathrm{cm}$ failed to reveal any remnants of volcanic debris. The other alternative is that opal-CT replacement of the original carbonate and the resultant authigenic carbonate formation around the nodule occurred only after deep burial where the pore waters were already light. Clearly the question of chert formation and its effect on the isotopic composition of associated carbonates deserves more study.

Sample $367-34-4,20-23 \mathrm{~cm}$ (W) is also very light $\left(-6.4^{\circ} \% 0\right)$. Equilibrium precipitation of this sample in ocean water would require a temperature around $50^{\circ} \mathrm{C}$. It seems unlikely that the geothermal gradient is that high $\left(5^{\circ} \mathrm{C} / 100 \mathrm{~m}\right)$ in these sediments. Although this sample appears in hand specimen to be a normal chalk, it contains only $35 \%$ carbonate. SEM micrographs (Plate 2, Figures 4 and 5) show grains comparable in appearance to silicates in other studies (Eade and Anderson, 1975, Plate 1, Figure 4). This authigenic silicate formation could have produce pore waters locally depleted in $0^{18}$.

\section{Effect of Clay Content}

When sampling material from Site 367 , particular attention was given to small-scale lithology changes within individual cores. Twenty pairs of samples from Site 367 taken within $40 \mathrm{~cm}$ of each other differed from each other by over $10 \%$ in carbonate content (Table 2). Another such pair had previously been sampled from Site 105. In 17 of the 21 cases examined, the sample which had the higher carbonate content was depleted in $0^{18}$, in some cases by up to $3 \%$. Two of the other cases occurred very near basaltic basement and differred from each other only marginally in isotopic composition. The remaining two cases involve chert nodules and have been discussed above.

Variations in ocean conditions could induce primary isotopic variations in two ways. The isotopic composition of carbonate secreted by planktonic organisms could change because of changes in the temperature or isotopic composition of ocean water. Alternatively, selective dissolution could control the composition of the sediment as it is being deposited by preferentia-ly dissolving a part of the sediment having some characteristic isotopic composition. Generally near-surface, warm-water forms are more susceptible to dissolution than the more robust, deeper living types (Berger, 1968).

Regular variations in the carbonate content of Quaternary cores have been documented by Arrhenius (1952), Hays et al. (1969), Hays and Perruzza (1972), Olausson (1971), and Gardner (1975) among others. These variations appear to coincide with glacialinterglacial cycles and are the result of changes in productivity and dissolution which are primarily caused by changes in circulation (Olausson, 1971; Ramsay, 1974) and changes in noncarbonate influx (Ruddiman, 1971; Gardner, 1975). Associated isotopic variations are primarily due to changes in the isotopic composition of ocean water caused by changes in the size of continental ice sheets (Shackleton and Opdyke, 1974). Jurassic sediments at Site 367 , also present at Site 105 (Lancelot et al., 1972), are directly analogous to those observed in the Quaternary record because large-scale continental ice sheets did not exist at those times. Although glaciation was not widespread before the Oligocene or Miocene, carbonate cycles are

TABLE 2

Relationship Between Isotopic Composition and Carbonate Content

\begin{tabular}{|c|c|c|c|}
\hline Sample (Interval in $\mathrm{cm}$ ) & $\triangle \% \mathrm{CaCO}_{3}$ & $\Delta_{\delta} 0^{18}$ & $\Delta_{\delta} \mathrm{C}^{13}$ \\
\hline $105-21-1,62-63$ vs $105-21-1,53-54$ & 32.9 & -0.56 & -0.80 \\
\hline $367-25-1,9-10$ vs $367-25-1,14-15$ & 52.2 & -0.52 & -1.42 \\
\hline $367-25-3,59-61$ (L) vs $367-25-3,59-61$ (D) & 25.8 & -1.09 & -0.44 \\
\hline $367-26-1,67-69$ (WC) vs $367-26-1,67-69$ (GC) & 24.7 & -0.96 & -0.31 \\
\hline $367-27-2,137-139$ (W) vs $367-27-2,137-139$ (G) & 36.2 & -1.58 & -0.62 \\
\hline $367-28-1,134-136$ vs $367-28-1,113-114$ & 13.5 & -0.50 & -0.12 \\
\hline $267-28-3,108-109$ vs $367-28-3,69-71$ & 20.7 & -2.12 & -0.57 \\
\hline $367-29-1,109-111$ (LC) vs $367-29-1,109-111$ (UC) & 16.0 & +1.15 & +0.04 \\
\hline $367-30-1,59-60$ vs $367-30-1,72-73$ & 36.5 & -0.46 & -0.21 \\
\hline $367-30-1,87$ vs $367-30-1,72-73$ & 31.5 & -1.13 & -0.19 \\
\hline $367-30-1,87$ vs $367-30-1,112-113$ & 13.9 & -0.07 & +0.03 \\
\hline $367-31-1,65-67$ (C1) vs $367-31-1,65-67$ (C2) & 56.0 & +1.56 & +0.39 \\
\hline $367-32-3,86-87$ (WC) vs $367-32-3,86-87$ (GC) & 47.3 & -0.88 & +0.00 \\
\hline $367-33-2,67-69$ vs $367-33-2,75-77$ & 46.0 & -0.40 & +0.06 \\
\hline $367-34-1,107-109$ vs $367-34-1,105-106$ & 74.6 & -2.99 & +0.36 \\
\hline $367-34-3,104-105$ (W) vs $367-34-3,104-105(R)$ & 66.6 & -1.83 & +0.16 \\
\hline $367-34-4,20-23$ (W) vs $367-34-4,20-23$ (G) & 23.7 & -3.19 & -0.07 \\
\hline $367-35-4,61-63$ vs $367-35-4,51-53$ & 81.7 & -2.03 & +0.45 \\
\hline $367-36-3,23-25$ (G) vs $367-36-3,23-25(P)$ & 15.7 & -0.26 & -0.10 \\
\hline $367-38-1,148-149$ vs $367-38-1,143-144$ & 26.1 & +0.17 & +0.12 \\
\hline $367-38-2,9-10(\mathrm{G})$ vs $367-38-2,9-10(\mathrm{R})$ & 18.8 & +0.50 & +0.04 \\
\hline $367-38-2,35-36$ vs $367-38-2,9-10$ (G) & 13.8 & -2.12 & -0.17 \\
\hline
\end{tabular}


common in early Tertiary and older sediments (Arthur and Roggenthen, 1976). The causes of earlier fluctuations are completely unknown. It is difficult, however, to explain why such primary variations in carbonate content should result in variations in the primary isotopic composition of the magnitude and direction observed.

Oldershaw and Scoffin (1967) suggest that clay-rich zones in limestone sequences can serve as important contributors of cement to surrounding regions. Arthur and Roggenthen (1976) report that although primary variations exist in carbonate content, these variations are enhanced by diagenetic effects. Clay-rich zones are regions of intense carbonate dissolution. The carbonate thus dissolved precipitates in the immediately adjoining, carbonate-rich, regions where void spaces (sites of low pressure) are more common. Weyl (1959) provides a theoretical basis for the catalytic effect of clay in his treatment of pressure solution. He suggests that water films between grains are much thicker when a layer of clay is also present. These thicker films should provide for faster diffusion of ions away from the sites of dissolution to the sites of reprecipitation. Clays may also produce chemical effects which would produce the same results.

Carbonate precipitated at the higher temperatures of deep burial should be depleted in $0^{18}$ relative to original carbonate. The isotopic data would be explained if the clay-poor zones contain a substantially larger fraction of authigenic calcite formed at elevated temperatures than do the clay-rich zones. Clay-poor sediments near to a clay-rich zone should have more authigenic calcite than do clay-poor sediments further away from the clay-rich zone. Sample 367-34-1, 105-106 cm has a low carbonate content (18.4\%). Sample 367-34-1, 107-109 $\mathrm{cm}$ is almost pure carbonate $(92.8 \%)$ as is Sample $367-$ $34-3,137-139 \mathrm{~cm}(90.0 \%)$. The oxygen isotope composition of $(107-109 \mathrm{~cm})$ is much lighter than $(105-$ $106 \mathrm{~cm})$ and slightly lighter than $(137-139 \mathrm{~cm}$ ) (Table $1)$. This pattern is consistent with the clay-rich zone serving as a source of carbonate for the surrounding region.

The explanation for the isotopic results given above is tentative and should be viewed with caution. The idea that clay zones undergo more intense dissolution explains the isotope data, but is difficult to reconcile with other facts. Preservation of the nannofossils at Site 105 is reported to be much better in the clay-rich zones than in clay-poor regions (Lancelot et al., 1972), and this phenomenon is common in deep-sea carbonates (Wise, oral communication, 1976). The preliminary results of SEM work on these samples is inconclusive (Plate 2, Figures 7-12) although Jansa (this volume) reports on the basis of his studies that diagenetic alteration is greater in limestones with lesser amounts of argillaceous material.

Lancelot et al. (1972), suggest that this differential preservation is because "the clay minerals prevent the minimum circulation required for the reprecipitation of calcite in intergranular spaces." If the clay-rich regions did not undergo recrystallization to as great an extent as carbonate-rich regions did, then the isotopic pattern illustrated by Table 2 would be explained. This explanation seems incorrect for two reasons. First, there is no a priori reason for assuming any circulation is required for recrystallization, especially if recrystallization is driven by pressure solution. Second, Brenneke and Anderson (1975) observed this same isotopic relationship in other sediments from Leg 11. Some of the clay-rich zones in these sediments contain up to $50 \%$ authigenic dolomite. If ion mobility is sufficient to allow this amount of dolomite to form, calcite should be able to recrystallize.

The pressure solution explanation is not without difficulties either. Plate 2, Figure 9, shows half of a well-preserved coccosphere from a clay-rich zone at Site 367. The pore space within this coccosphere has not been filled by carbonate even though it is closer to the site of pressure solution than is the nearby carbonate-rich zone. Perhaps the best explanation is that clays affect the chemistry of the pore waters in some way not well understood.

\section{Carbon Isotope Results}

The relation of $\delta \mathrm{C}^{13}$ to carbonate content is not nearly as consistent as it is for $\delta 0^{18}$ (Table 2). In general, less deeply buried samples show a depletion in $\delta \mathrm{C}^{13}$ from clay-rich to carbonate-rich zones, whereas those samples more deeply buried exhibit the reverse.

The carbon isotopic compositions of sediments from Sites 105 and 367 are plotted against depth in Figures 3 and 4 , respectively. Whereas too few samples were analyzed at Site 105 to show any small-scale variation with depth, it can be seen that the carbon values from Site 367 vary cyclically over a range of $2 \%$. These variations seem independent of lithology or degree of recrystallization and are assumed to be primary. The carbon isotopic composition of biogenic carbonate depends upon the isotopic composition of dissolved inorganic carbon and various species-dependent "vital" effects (Shackleton et al., 1973; Savin and Douglas, 1973). Because bulk samples of carbonate were analyzed, it is assumed that any species-dependent fractionation was averaged out.

The isotopic composition of dissolved inorganic carbon in seawater varies with depth from about $+2^{\circ} / 00$ at the surface to as low as $-0.5^{\circ} \%$ at the oxygen minima (Craig, 1970; Kroopnick et al., 1970; Kroopnick et al., 1972; Kroopnick, 1974b). Changes in the depth at which carbonate formed from very near the surface to the depth of the oxygen minima ( 400 to $500 \mathrm{~m}$ ) could produce $\delta \mathrm{C}^{13}$ variations of the magnitude seen at Site 367. Much of the carbonate in the sediments from Site 367 is produced by calcareous algae (Coccolithiphoridaceae) which must calcify within the photic zone, so that the preceding explanation is untenable. Therefore, the $\delta \mathrm{C}^{13}$ variations measured at Site 367 reflect variations in the isotopic composition of dissolved inorganic carbon in the near-surface waters of the ocean. These variations could be caused by either changes in the isotopic composition of the oceanic resevoir of carbon or by changing the partitioning of $\delta \mathrm{C}^{13}$ between surface and deep water.

The isotopic composition of dissolved inorganic carbon in the near-surface waters of the ocean is controlled by several processes: (1) a steady-state 
quasi-equilibrium with the atmosphere (Kroopnick, 1974a,b); (2) the net flux of carbon to and from the surface zone in the form of organic matter; and (3) the equivalent net flux of carbon in the form of carbonate. Because the total net flux of carbon to and from the surface zone must be zero, processes (2) and (3) must be about equal in magnitude and opposite in sign (some $\mathrm{CO}_{2}$ is also transported across the seawater-atmosphere interface).

The quasi-equilibrium between dissolved inorganic carbon and the atmosphere is a function of temperature, atmospheric $\mathrm{PCO}_{2}$, and the $p \mathrm{H}$ (or alkalinity) of the water (Kroopnick, 1974a). Local changes in any of these variables could produce local changes in the isotopic composition of dissolved inorganic carbon for perhaps as long as a few thousand years. Because the oceanic reservoir of carbon is 60 times as large as the atmospheric reservoir (Garrels et al., 1974), a world-wide change in any of the variables would have very little effect on the oceanic reservoir although the effect on the atmospheric reservoir could be quite large.

Such stability in the oceanic carbon reservoir would not be true if the composition of the atmosphere should continue to change for a long period of time. Terrestrial organic carbon is depleted in $\mathrm{C}^{13}$ relative to the atmospheric reservoir by about $18 \%$ (Craig, 1953). Silverman $(1961,1962)$ suggests that the evolution of land plants fixed sufficient light carbon to change the isotopic composition of the atmosphere and that these changes could explain trends in the $\mathrm{C}^{13} / \mathrm{C}^{12}$ ratio of petroleum with time. A change in the average net preservation resulting in the burial of an additional 2.5 $\mathrm{x} 10^{17}$ moles of fixed carbon would be sufficient to produce the variation of $2 \%$ in the oceanic reservoir observed at Site 367. This change in preservation could, for example, be due to the existence of very extensive coal swamps or to the rapid exposure and oxidation of previously buried organic matter which might accompany rapid uplift and accelerated erosion.

Variations in the net removal of organic carbon from the surface region could have as much effect on the isotopic composition of total $\mathrm{CO}_{2}$ as variations in the preservation of terrestrial organic matter. Marine organic carbon is depleted in $\mathrm{C}^{13}$ relative to dissolved inorganic carbon by between 12 and $28 \%$, depending upon environmental factors, with an average of around $20^{\circ} \%$ (Degens, 1969). Carbonate carbon is roughly similar in isotopic composition to dissolved inorganic carbon (Kroopnick, 1974b). The isotopic composition of dissolved carbon is thus much more sensitive to the net flux of organic carbon than to the flux of carbonate carbon.

The net flux of organic carbon in the surface zone depends upon the rate of production of organic matter, the rate at which this organic matter is oxidized in the surface zone, the rate at which $\mathrm{CO}_{2}$ from deep water is returned to the surface zone by upswelling, the fraction of $\mathrm{CO}_{2}$ in deep water which is produced by the oxidation of organic matter, and the amount of $\mathrm{CO}_{2}$ produced by the oxidation of organic matter (either recent or fossil) which is carried into the ocean by rivers. The same factors control the net removal of carbon in the form of carbonate with the dissolution of carbonate substituting for oxidation of organic matter.

The individual processes which control the net removal of carbon are not independent. The rate of production of organic matter in the ocean depends principally upon the supply of nutrients, primarily phosphorous. The supply of $P$ depends upon the rate of upwelling of nutrient-rich deep water and the rate of $P$ influx from the land by river discharge. The amount of organic matter oxidized and contributed to the deepwater mass depends upon the rate of production or organic matter and on the amount of oxygen in the deep water. This latter depends upon the rate of formation of deep water, which, through conservation of mass, must equal the rate of upwelling.

An increase in ocean circulation would increase the supply of $P$ to the surface zone and thereby increase the rate of production of organic matter. This would leave the dissolved inorganic carbon reservoir in the surface zone enriched in $\delta \mathrm{C}^{13}$. This enrichment would be reflected in the isotopic composition of carbonate forming in this water. However, oxidation of the increased flux of organic matter would increase the $\mathrm{CO}_{2}$ content of deep water and decrease its $\delta \mathrm{C}^{13}$ value. Oceanic circulation would carry this light $\mathrm{CO}_{2}$ back up to the surface zone, shifting the surface reservoir back towards its original composition. It is likely that increased production of organic matter would be accompanied by an increase in carbonate secretion. The higher $\mathrm{CO}_{2}$ content of the deep water would decrease its $\mathrm{PH}$ and increase the dissolution of carbonate.

All of the feedback in the ocean need not occur in one geographic locale. The increased amounts of oxidized organic carbon need not be returned to the surface by upwelling deep water at the exact locality where the increased organic production occurs. Local changes in the $\delta \mathrm{C}^{13}$ of the inorganic carbon in the surface ocean (about $1^{\%} \%$, Kroopnick, 1971, 1974a). Most of this variation is across the Antartic convergence where deep and surface waters mix freely. Although this is a region of extraordinarily high productivity, the influx of light carbon by upwelling is greater than removal by organic activity and the isotopic composition of dissolved inorganic carbon in this region is lighter than most of the rest of the ocean (Kroopnick, 1971, 1974a).

The net effect of a change in the oceanic mixing rate on the isotopic composition of dissolved inorganic carbon would depend upon changes in the amount of organic carbon preserved in the sediments. The dependence of the amount of organic carbon preserved on the mixing rate is not known, but the range of possible effects can be estimated by considering two limiting cases. In case 1 the amount of organic carbon preserved is assumed to be independent of the mixing rate. In this case the isotopic composition of dissolved inorganic carbon is also independent of the mixing rate. In case 2 the fraction of organic matter preserved is assumed to be independent of the mixing rate. With this assumption, it can be shown that doubling the oceanic mixing rate would increase the isotopic composition of the oceanic reservoir of carbon by about $1.2 \%$ (Brenneke, in preparation). 
Broecker $(1971,1974)$ stresses that the partitioning of $\delta \mathrm{C}^{13}$ between the deep and surface water masses is a function of the ratio of $\mathrm{C} / \mathrm{P}$ in deep water to that in organisms. In case 1 above, this ratio is independent of the mixing rate. In case 2 , however, doubling the mixing rate would raise the $\mathrm{C} / \mathrm{P}$ ratio in deep water and decrease the enrichment of $\mathrm{C}^{13}$ in the surface ocean from the present 2 to $3 \%$ (Craig, 1970; Kroopnick et al., 1970; Kroopnick et al., 1972; Kroopnick, 1971, $1974 \mathrm{~b}$ ) to about $1.2^{\circ} \%$ (Brenneke, personal communication).

The ratio of $\mathrm{C} / \mathrm{P}$ in deep water to that in organisms could change in other ways. There is no a priori reason to believe that the $\mathrm{C} / \mathrm{P}$ ratio in organisms has remained constant through time. If Broecker's analysis is correct, doubling the $\mathrm{C} / \mathrm{P}$ ratio in organisms would double the isotopic difference between carbon in the surface and deep reservoirs. Halving the $\mathrm{C} / \mathrm{P}$ ratio in organisms would the difference between the surface and deep reservoirs. Similar effects would result if changes in the rate of carbonate formation decreased or increased the carbon content of the ocean by $50 \%$. The $\mathrm{C} / \mathrm{P}$ ratio in the ocean is also sensitive to the rate of phosphorite formation. Large changes in the rate of $\mathrm{P}$ removal in this form, or large changes in the rate of $\mathrm{P}$ input by rivers due to varying erosion of phosphorites, would also change the isotopic difference between surface and deep water. In each case the carbon isotopic composition of deep-sea carbonates would reflect the changes in the isotopic composition of dissolved inorganic carbon in the surface waters.

Several other workers have noted the existence of periodic variations in the isotopic composition of marine carbonates. Jeffery et al. (1955), Compston (1960), Weber (1967), and Tappan (1968) all discussed variations based on average values for geologic periods. Thus the average carbon isotope composition of marine limestone of Cretaceous age is heavier than the average composition of similar limestone of Jurassic age (Weber, 1967). Because average compositions for each period were obtained from samples worldwide in distribution, resolution of variations on the time scale discussed here was not possible. In fact, the scatter over a given geologic period is so large (as can easily be visualized from Figure 4) that two co-authors, using the same data, reached opposite conclusions as to the actual existence of such variations (Keith and Weber, 1964; Weber, 1967). Explanations for these long-period fluctuations range from periodic diastrophism (Jeffery et al., 1955; Compston, 1960) to the evolution of land plants (Weber, 1967) to changes in nutrient supply from the continents because of topographic and climatic changes (Tappan, 1968). All of these explanations seem to require too long a time to operate to be responsible for the variations observed here.

Douglas and Savin (1973) and Shackleton and Kennett $(1975 a, b)$ have observed fluctuations in the $\delta \mathrm{C}^{13}$ of younger marine carbonates similar to those observed here. They also concluded that these variations reflect variations in the isotopic composition of dissolved inorganic carbon. They offered no explanation for these shifts. Fluctuations of much shorter duration have been found in Pleistocene cores by Sommer and Matthews (1975) and Anderson and Adelseck (unpublished data). Sommer and Matthews suggest that these variations are worldwide in extent and suitable for stratigraphic purposes. If the variations found at Site 367 and those seen by Douglas and Savin (1973) and Shackleton and Kennett (1975a) are also found to be of worldwide extent, then they offer a new stratigraphic tool for older, relatively recrystallized cores which are difficult to date precisely by other methods.

\section{CONCLUSIONS}

1) Vein-filling carbonates begin to form at oceanfloor temperatures, in equilibrium with seawater, shortly after the basalt has cooled. Vein formation continues in the presence of isotopically light pore waters which are formed by the weathering of basalt to authigenic silicates. Poor communication between the pore water in the fracture systems and the ocean allows very light veins to form at relatively low temperatures.

2) The lack of any isotopic evidence of high temperature "baking" of the lowermost sediments at either Site 105 or Site 367 suggests that the basalts at both sites were extrusive or intruded only a very thin sediment pile.

3) Sediments from Site 367 are depleted in $0^{18}$ relative to correlative sediments from Site 105 due to the greater degree of recrystallization at higher temperatures and possibly in the presence of lighter pore waters which has occurred at Site 367 . The degree of recrystallization and temperature of recrystallization are both functions of the thickness of overburden. The lighter pore waters, if present, could be caused by greater amounts of authigenic silicates having been formed at Site 367.

4) The sediments immediately overlying the basalt at Site 367 are less recrystallized and isotopically heavier in oxygen than the sediments immediately above them. The isotope data suggest that much of this recrystallization occurred at relatively low temperatures and thus at relatively shallow burial depth. The cause of such early recrystallization and the reason why further recrystallization did not occur in these sediments are unknown.

5) Carbonates closely associated with two chert nodules at Site 367 tend to be depleted in $0^{18}$ relative to all other sediments. No good explanation for these data is currently available. Present assumptions regarding the precursor of nodular chert or the timing of the onset of chertification may have to be revised.

6) The amount of clay in carbonate sediments significantly influences the oxygen isotope composition and degree of recrystallization of those sediments. Clays may produce these effects by their influence on pressure solution, pore water chemistry, or fluid movement.

7) The carbon isotopic composition of carbonates from Site 367 varies systematically with depth. These variations are believed to be primary and related to the isotopic composition of dissolved inorganic carbon in the ocean. These variations are presumably caused by changes in the amount of organic carbon buried in sediments or by changes in the $\mathrm{C} / \mathrm{P}$ ratio in ocean water. Data from Site 105 are insufficient to test the possibility of using carbon isotope variations in Cretaceous and older deep-sea carbonates as a stratigraphic tool. 


\section{ACKNOWLEDGMENTS}

Drs. P.A. Sandberg and T.F. Anderson reviewed earlier versions of this manuscript and made many helpful suggestions. S. Dreifuss provided invaluable help with the scanning electron microscope. The isotope geochemical laboratory at the University of Illionis is supported in part by NSF Grant GA-1680. The author gratefully acknowledges the support of an NSF graduate fellowship.

\section{REFERENCES}

Anderson, T.F., 1973. Oxygen and carbon isotope compositions of altered carbonates from the Western Pacific, Core 53.0, DSDP. Mar. Geol. v. 15, p. 169-180. , in preparation. Stable isotopic evidence for the origin of carbonate veins in oceanic volcanics.

Anderson, T.F., and Lawrence, J.R., (1976). Stable isotope investigations of sediments, basalts, and authigenic phases from Leg 35 cores. In Initial Reports of the Deep Sea Drilling Project, Volume 35. Washington (U.S. Government Printing Office) p. 497-505.

Anderson, T.F. and Schneidermann, N., 1973. Stable isotope relationships in pelagic limestones from the Central Caribbean: Leg 15, Deep Sea Drilling Project. In Edgar, N.T., Saunders, J.B., et al., Initial Reports of the Deep Sea Drilling Project, Volume 15: Washington (U.S. Government Printing Office), p. 795-803.

Arrhenius, G., 1952. Sediment cores from the East Pacific: Rept. Swedish Deep-Sea Exped., v. 5, p. 1-227.

Arthur, M.A. and Roggenthen, W.M., 1976. Primary bedding rhythms in pelagic calcareous sediments (abstract): Prog. AAPG-SEPM Ann. Convention, v. 2, p. 39.

Berger, W.H., 1968. Planktonic foraminifera: Selective solution and paleoclimatic interpretation: Deep-Sea Res., v. 15 , p. $31-43$.

Bernoulli, D., 1972. North Atlantic and Mediterranean Mesozoic facies: A comparison. In Hollister, C.D., Ewing, J.I., et al., Initial Reports of the Deep Sea Drilling Project, Volume 11: Washington (U.S. Government Printing Office), p. 801-871.

Broecker, T.F., and Lawrence, J.R., (1976). Stable isotope investigations of sediments, basalts, and authigenic phases from Leg 35 cores. In Hollister, C.D., Craddock, C., et al., Initial Reports of the Deep Sea Drilling Project, Volume 35: Washington (U.S. Government Printing Office), p. 497-505.

Broecker, W.S., 1971. A kinetic model for the chemical composition of sea water. Quat. Res., v. 1, p. 188-207.

(Har, 1974. Chemical oceanography: New York (Harcourt Brace Hovanovich, Inc.), p. 214.

Brenneke, J.C. and Anderson, T.F., 1975. Stable isotope studies of Leg 11 carbonates: Implications for diagenesis and lithification in the deep sea (abstract): EOS, Trans., Am. Geophys. Union, v. 56, p. 371.

Compston, W., 1960. The carbon isotope composition of certain marine invertebrates and corals from the Australian Permian: Geochim. Cosmochim. Acta, v. 18, p. 1-22.

Craig, H., 1953. The geochemistry of the stable carbon isotopes: Geochim. Cosmochim. Acta, v. 3, p. 53-92. 1957. Isotopic standards for carbon and oxygen and correction factor for mass-spectrometric analysis of carbon dioxide: Geochim. Cosmochim. Acta, v. 12, p. 133-149.

1965. The measurement of oxygen isotope paleotemperatures. In Tongiorgi, E. (Ed). Stable isotopes in oceanographic studies and paleotemperatures, Spoleto, July 26-30, 1965: Pisa (Consiglio Nazionale delle Ricerche Laboratoriodi Geologia Nucleare), p. 1-24.
1970. Abyssal carbon-13 in the South Pacific: J. Geophys. Res., v. 75, p. 691-695.

Douglas, R.G. and Savin, S.M., 1973. Oxygen and carbon isotope analyses of Cretaceous and Tertiary foraminifera from the Central North Pacific. In Winterer, E.L., Ewing, J.I., et al., 1973. Initial Reports of the Deep Sea Drilling Project, Volume 17: Washington (U.S. Government Printing Office), p. 591-605.

Degens, E.T., 1969. Biogeochemistry of stable carbon isotopes. In Eglington, G. and Murphy, M.T.T. (Eds.). Organic geochemistry: New York (Springer-Verlag), p. 304-329.

Eade, J.V. and Anderson, T.F., 1975. Oxygen and carbon isotope composition and diagenesis of Eocene clay nannochalk at DSDP Site 287, Coral Sea Basin, Leg 30, DSDP. In Andrews, J.E., Packham, G., et al., Initial Reports of the Deep Sea Drilling Project, Volume 30: Washington (U.S. Government Printing Office), p. 419-422.

Edgar, N.T., Saunders, J.B., et al., 1973. Initial Reports of the Deep Sea Drilling Project, Volume 15: Washington (U.S. Government Printing Office).

Emiliani, C., 1954. Temperatures of Pacific bottom waters and polar superficial waters during the Tertiary: science, v. 119, p. $853-855$.

Gardner, J.V., 1975. Late Pleistocene carbonate dissolution cycles in the Eastern Equatorial Atlantic. In Sliter, W.V., Be, A.W.H., and Berger, W.H. (Eds.), Dissolution of deep-sea carbonates: Cushman Found. Foram. Res., Spec. Publ. 13. p. 129-141.

Garlick, G.P. and Dymond, J.R., 1970. Oxygen isotope exchange between volcanic materials and ocean water: Geol. Soc. Am. Bull, v. 81, p. 2137-2142.

Garrels, R.M., Mackenzie, F.T., and Hunt, C., 1974. Man's contributions to natural chemical cycles: Evanston, Ill. (Northwestern University Press).

Garrison, R.E., Hein, J.R., and Anderson, T.F., 1973. Lithified carbonate sediment and zeolitic tuff in basalts, Mid-Atlantic Ridge: Sedimentology, v. 20, p. 399-410.

Gieskes, J.M. and Lawrence, J.R., 1976. Interstitial water studies, Leg 35. In Hollister, C.D., Craddock, C., et al., Initial Reports of the Deep Sea Drilling Project, Volume 35: Washington (U.S. Government Printing Office), p. 407-424.

Hays, J.D. and Perruzza, A., 1972. The significance of calcium carbonate oscillations in Eastern Equatorial Atlantic deep-sea sediments for the end of the Holocene warm interval: Quat. Res., v. 2, p. 355-362.

Hays, J.D., Saito, T., Opdyke, N.D., and Burckle, L.H., 1969. Pliocene-Pleistocene sediments of the Equatorial Pacific: Their paleomagnetic biostratigraphy and climatic record. Geol. Soc. Am. Bull., v. 80, p. 1481-1514.

Heath, G. R., 1973. Cherts from the Eastern Pacific, Leg 16, Deep Sea Drilling Project. In van Andel, T.H., Heath, G.R., et al., Initial Reports of the Deep Sea Drilling Project, Volume 16: Washington (U.S. Government Printing Office), p. 609-613.

Heath, G.R., and Moberly, R., Jr., 1971. Winterer, E.L., Riedel, W.R., et al., Cherts from the Western Pacific,, Leg 7, Deep Sea Drilling Project. Washington (U.S. Government Printing Office), In Initial Reports of the Deep Sea Drilling Project, Volume 7: p. 991-1007.

Hollister, C.D., Ewing, J.I., et al., 1972. Initial Reports of the Deep Sea Drilling Project, Volume 11: Washington (U.S. Government Printing Office).

Jeffery, P.M., Compston, W., Greenhalch, D., and Lafter, J.de, 1955. On the carbon 13 abundance of limestones and coals: Geochim. Cosmochim. Acta, v. 7, p. 255-286.

Keene, J.B., 1975. Cherts and porcellanites from the North Pacific, DSDP Leg 32. In Larson, R.L., Moberly, R., et al., Initial Reports of the Deep Sea Drilling Project, 
Volume 32: Washington (U.S. Government Printing Office), p. 429-507.

Keith, M.L. and Weber, J.N., 1964. Carbon and oxygen isotopic composition of selected limestones and fossils: Geochim. Cosmochim. Acta, v. 28, p. 1787-1816.

Knauth, L.P. and Epstein, S., 1975. Hydrogen and oxygen isotope ratios in silica from the JOIDES Deep Sea Drilling Project. Earth Planet. Sci. Lett., v. 25, p. 1-10.

Kroopnick, P.M., 1971. Oxygen and carbon in the oceans and atmosphere: Stable isotopes as tracers for consumption, production, and circulation models. Unpublished Ph.D. Thesis, University of California, San Diego, p. 257.

1974a. Correlations between ${ }^{13} \mathrm{C}$ and $\mathrm{CO}_{2}$ in surface waters and atmospheric $\mathrm{CO}_{2}$ : Eart Planet Sci. Lett., v. 22, p. 397-403.

1974b. The dissolved $\mathrm{O}_{2}-\mathrm{CO}_{2-}{ }^{13} \mathrm{C}$ system in the Eastern Equatorial Pacific: Deep-Sea Res., v. 21, p. 211227.

Kroopnick, P., Deuser, E.G., and Craig, H., 1970. Carbon 13 measurements on dissolved inorganic carbon at the north Pacific (1969) Geosecs Stations: J. Geophys. Res., v. 75, p. $7668-7671$.

Kroopnick, P., Weis, R.F., and Craig, H., 1972. Total $\mathrm{CO}_{2}$, ${ }^{-13} \mathrm{C}$, and dissolved oxygen ${ }^{18} 0$ at GEOSECS II in the North Atlantic: Earth Planet Sci. Lett., v. 16, p. 103-110.

Lancelot, Y., 1973. Chert and silica diagenesis in sediments from the Central Pacific. In Winterer, E.L., Ewing, J.L., et al., Initial Reports of the Deep Sea Drilling Project, Volume 17: Washington (U.S. Government Printing Office), p. 377-405.

Lancelot, Y., Hathaway, J.C., and Hollister, C.D., 1972. Lithology of sediments from the Western North Atlantic Leg 11 Deep Sea Drilling Project. In Hollister, C.D., Ewing, J.I., et al., Initial Reports of the Deep Sea Drilling Project, Volume 11: Washington (U.S. Government Printing Office), p. 901-949.

Langseth, M.G., 1965. Techniques of measuring heat flow through the ocean floor. In Lee, W.H.K. (Ed.), Terrestrial heat flow: Am. Geophys. Union Geophys. Mono. 8, p. 58-77.

Lawrence, J.R., 1973. Interstitial water studies, Leg 15-Stable oxygen and carbon isotope variations in water, carbonates, and silicates from the Venezuela Basin (Site 149) and the Aves Rise (Site 148). In Heezen, B.C., MacGregor, I.D., et al., Initial Reports of the Deep Sea Drilling Project, Volume 20: Washington (U.S. Government Printing Office). p. 891-899.

1974. Stable oxygen and carbonate isotope variations in the pore waters, carbonates and silicates, Sites 225 and 228, Red Sea. In Whitmarsh, R. B., Weser, O.E., Ross, D.A., et al., Initial Reports of the Deep Sea Drilling Project, Volume 23: Washington (U.S. Government Printing Office), p. 939-942.

Lawrence, J.K., Gieskes, J.R., and Broecker, W.S., 1975. Oxygen isotope and cation composition of DSDP pore waters and the alteration of layer II basalts: Earth Planet. Sci. Lett., v. 27, p. 1-10.

McCrea, J.M., 1950. On the isotopic chemistry of carbonates and paleotemperature scale: J. Chem. Phys. v. 18, p. 849 857.

Moore, J.G., Phillips, R.C., Grigg, R.W., Peterson, D.W., and Swanson, D.A., 1973. Flow of lava into the sea, 196971, Kilauea Volcano, Hawaii: Geol. Soc. Am. Bull., v. 84, p. $537-546$.

Mopper, K. and Garlick, G.D., 1971. Oxygen isotope fractionation between biogenic silica and ocean water: Geochim. Cosmochim. Acta, v. 35, p. 1185-1187.

Muehlenbachs, K. and Clayton, R.N., 1972. Oxygen isotope studies of fresh and weathered submarine basalts. Canadian J. Earth Sci., n. 9, p. 172-184.
Olausson, E., 1971. Quaternary correlations and the geochemistry of oozes. In Funnell, B.M. and Riedel, W. R. (Eds.), The micropalaeontology of oceans: Cambridge (Cambridge University Press), p. 375-398.

Oldershaw, A.E. and Scoffin, T.P., 1967. The source of ferroan and non-ferroand calcite cements in the Halkin and Wealock Limestones: Geol. J., v. 5, p. 309-320.

Owen, B.B. and Brinkley, S.R., Jr., 1941. Calculation of the effect of pressure upon ionic equilibria in pure water and in salt solutions: Chem. Rev., v. 29, p. 461-474.

Perry, E.A., Jr., Gieskes, J.M., and Lawrence, J.R., 1976. $\mathrm{Mg}, \mathrm{Ca}$ and $0^{18} / 0^{16}$ exchange in the sediment-pore water system, Hole 149, DSDP: Geochim. Cosmochim. Acta, v. 40 , p. $413-423$.

Pfefferkorn, G.E., 1970. Specimen Preparation Techniques. In Jahari, O. (Ed.), 3rd Ann. Scanning Electron Microscopy Symp. Proc.: ITT Res. Inst., p. 89-96.

Ramsay, A.T.S., 1974. The distribution of calcium carbonate in deep sea sediments. In Hay, W.W. (Ed.), Studies in paleo-oceanography: Soc. Econ. Paleon. Mineral. Spec. Pu. 20, p. 58-76.

Ruddiman, W.F., 1971. Pleistocene sedimentation in the Equatorial Atlantic: Stratigraphy and faunal paleoclimatology: Geol. Soc. Am. Bull., v. 82, p. 283-302.

Saito, T. and van Donk, J., 1975. Oxygen and carbon isotope measurements of Late Cretaceous and Early Tertiary foraminifera: Micropaleontology, v. 20, p. 152-177.

Savin, S.M. and Douglas, R.G., 1973. Stable isotope and magnesium geochemistry of Recent planktonic foraminifera from the South Pacific: Geol. Soc. Am. Bull., v. 84 , p. $2327-2342$.

Savin, S.M., Douglas, R.G., and Stehli, F.G., 1975. Tertiary marine paleotemperatures: Geol. Soc. Am. Bull., v. 86, p. 1499-1510.

Sayles, F.L. and Manheim, F.T., 1975. Interstitial solutions and diagenesis in deeply buried marine sediments: Results from the Deep Sea Drilling Project: Geochim. Cosmochim. Acta, v. 39, p. 103-127.

Sayles, F.L., Manheim, F.T., and Waterman, L.S., 1972. Interstitial water studies on small core samples, Leg 11. In Hollister, C.D., Ewing, J.I., et al., Initial Reports of the Deep Sea Drilling Project, Volume 11: Washington (U.S. Government Printing Office), p. 997-1008.

Scholle, P.A., 1976. Applications of North Sea chalk diagenetic studies of petroleum exploration problems (abstract): Prog. AAPG-SEPM Ann. Convention, v. 2, p. 93-94.

Sclater, J.G. and Francheteau, J., 1970. The implications of terrestrial heat flow observations on current tectonic and geochemical models of the crust and upper mantle of the earth: Geophys. J. Roy. Astr. Soc., v. 20, p. 509-542.

Shackleton, N.J. and Kennett, J.P., 1975a. Paleotemperature history of the Cenozoic and the initiation of Antarctic glaciation: Oxygen and Carbon isotope analyses in DSDP Sites 277, 279, and 281. In Kennett, J.P., Houtz, R.E., et al., Initial Reports of the Deep Sea Drilling Project, Volume 29: Washington (U.S. Government Printing Office), p. 743-755.

1975b, Late Cenozoic oxygen and carbon isotopic changes at DSDP Site 284: Implications for glacial history of the Northern Hemisphere and Antarctica. In Kennett, J.P., Houtz, R.E., et al., Initial Reports of the Deep Sea Drilling Project, Volume 29: Washington (U.S. Government Printing Office). p. 801-807.

Shackleton, N.J. and Opdyke, N.D., 1973. Oxygen isotope and paleomagnetic stratigraphy of Equatorial Pacific Core V28-238: Oxygen isotope temperatures and ice volumes on a $10^{5}$ year and $10^{6}$ year scale: J. Quat. Res., v. 3, p. 39-55. 
Shackleton, N.J., Wiseman, N.J., and Buckley, A., 1973. Non-equilibrium deposition between seawater and planktonic foraminifera tests: Nature, v. 242, p. 177-179.

Silverman, S.R., 1961. Evidence for an age effect in the carbon isotopic composition of natural organic materials (abstract): Geol. Soc. Am. Spec. Papers 68, p. 272. 1962. Effect of evolution of land plants on $C^{13} / C^{12}$ ratios of natural organic materials (abstract): J. Geophys. Res., v. 67, p. 1657.

Sommer, M.A. and Matthews, R.K., 1975. Carbon-13 stratigraphy in deep sea cores (abstract): Geol. Soc. Am. Abs. (Annual Mtg.): p. 1279-1280.

Tappan, H., 1968. Primary production, isotopes, extinctions and the atmosphere: Palaeogeogr., Palaeoclim., Palaeoecol., v. 4, p. 187-210.
Von Herzen, R.P., Fiske, R.J., and Sutton, G., 1971. Geothermal measurements on Leg 8. In Tracey, J.I., Jr., et al., Initial Reports of the Deep Sea Drilling Project, Volume 8: Washington (U.S. Government Printing Office), p. 837-849.

Weber, J.N., 1967. Possible changes in the isotopic composition of the oceanic and atmospheric carbon reservoir over time: Geochim. Cosmochim. Acta, v. 31, p. 2343-2351.

Weyl, P.K., 1959. Pressure solution and the force of crystallization: A phenomenological theory: J. Geophys. Res., v. 64, p. 2001-2025.

Wise, S.W. and Weaver, F.M., 1974. Chertification of oceanic sediments. In Hsu, K.J. and Jenkyns, H.C. (Eds.). Pelagic sediments on land and under the sea: Spec. Publ. Int. Assoc. Sediment., v. 1, p. 301-326. 



\section{PLATE 1}

(All figures are scanning electron micrographs.)

Figure 1 Sample 105-21-1, 62-63 cm. Recognizable coccolith debris abundant, overgrowths slight to moderate. Magnification $\times 5600$. Scale bar $=1$ $\mu \mathrm{m}$.

Figure 2 Sample 105-21-1, 62-63 cm. Recognizable coccolith debris common. Blocky debris may be authigenic or overgrown fragments of larger microfossils. Magnification $\times 5600$. Scale bar $=$ $2 \mu \mathrm{m}$.

Figures 3,4 Sample 105-33-1, 100-101 cm. Recognizable coccolith debris still abundant, overgrowths slight to moderate. "Wispy" appearance due to presence of authigenic (?) silicates (see also Plate 2, Figures 15). Magnification $\times 3250$. Scale bar $=2 \mu \mathrm{m}$.

Figure 5 Sample 105-38-2, 100-101 cm. Well-preserved coccolith inside a broken)calcisphere (?). Magnification $\times 2500$. Scale bar $=2 \mu \mathrm{m}$.

Figure 6 Sample 105-38-2, 100-101 cm. Well-preserved coccolith beside broken fragment of calcisphere (?). Magnification $\times 1240$. Scale bar $=5 \mu \mathrm{m}$.

Figure 7 Sample 367-31-1, 65-67 cm (C2). Rare coccolith still recognizable. Authigenic calcite abundant. Magnification $\times 1850$. Scale bar $=5 \mu \mathrm{m}$.

Figure 8 Sample $367-31-1,65-67 \mathrm{~cm}$ (C2). Higher magnification of another region of the same sample as Figure 7. Note crystal faces produced by overgrowths on coccolith in center. Magnification $\times 4700$. Scale bar $=1 \mu \mathrm{m}$.

Figure 9 Sample 367-34-1, 107-109 cm. Authigenic calcite abundant. Magnificent $\times 1300$. Scale bar $=5 \mu \mathrm{m}$.

Figure 10 Sample $367-35-5,51-53 \mathrm{~cm}$. Well-preserved coccolith to right of center. Sample only $6 \%$ carbonate (see also Plate 2, Figure 9). Magnification $\times 2340$. Scale bar $=2 \mu \mathrm{m}$.

Figure 11 Sample 367-35-4, 61-63 cm. Rare nannofossil debris (note edge of coccolith left of center). Authigenic calcite abundant. Sample is $84 \%$ calcite. Magnification $\times 2350$. Scale bar $=2 \mu \mathrm{m}$.

Figure 12 Sample 367-35-4, 61-63 cm. Overgrown nannofossil debris. Authigenic calcite dominates. Magnification $\times 6000$. Scale bar $=1 \mu \mathrm{m}$. 
PLATE 1

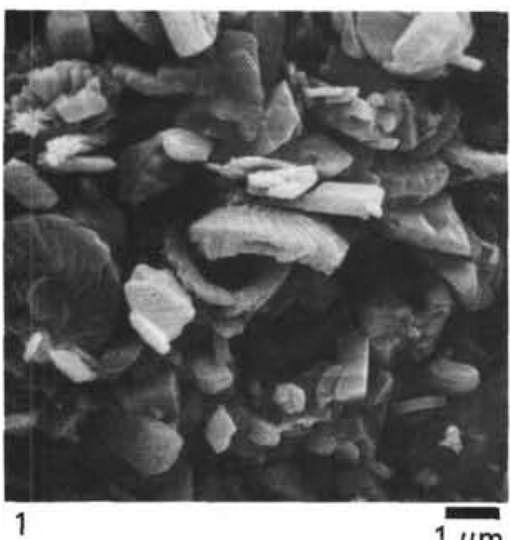

$1 \mu \mathrm{m}$
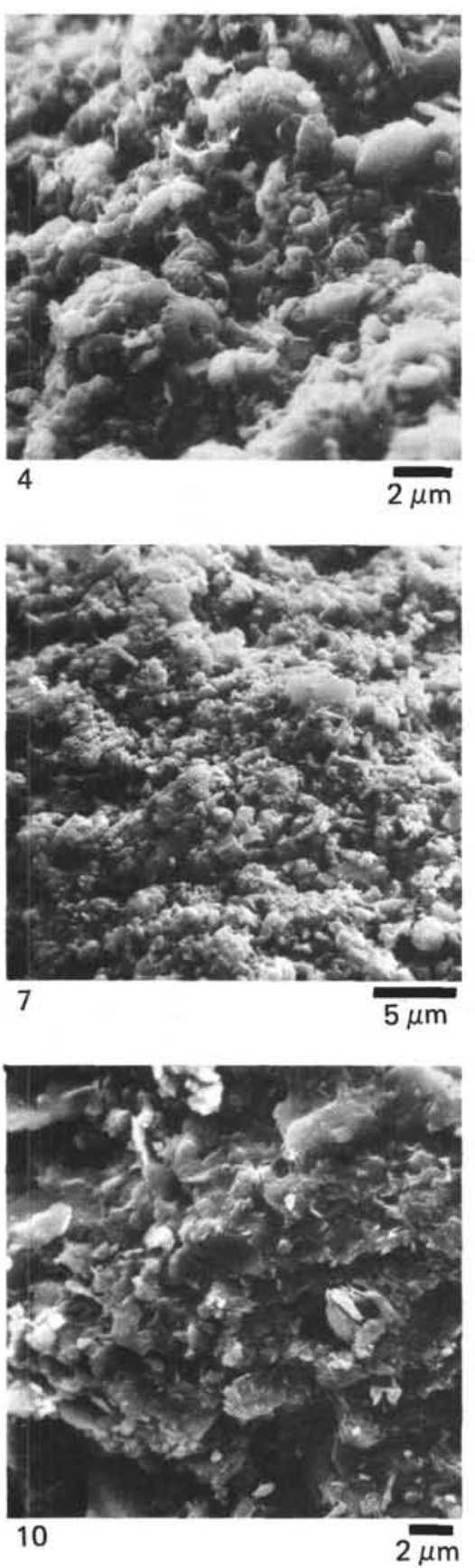
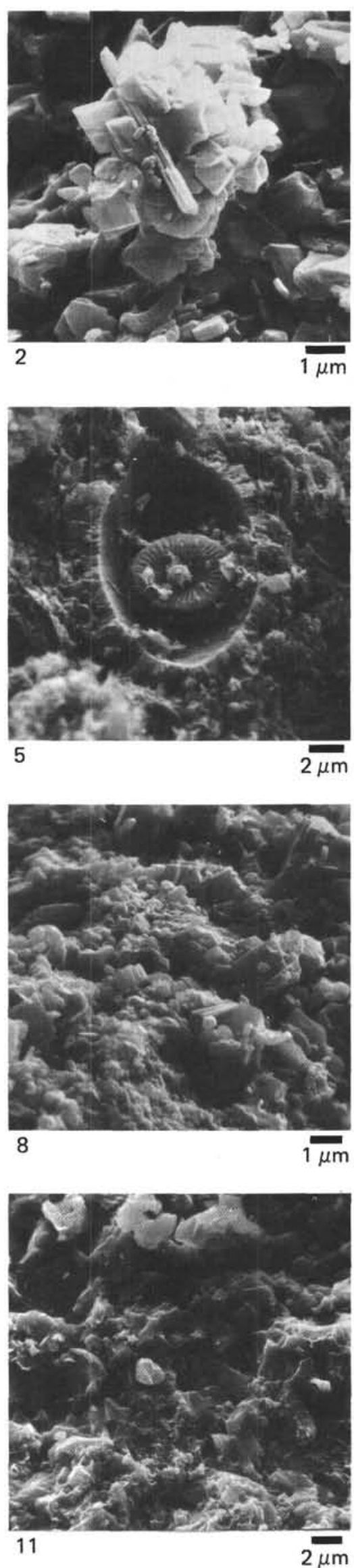
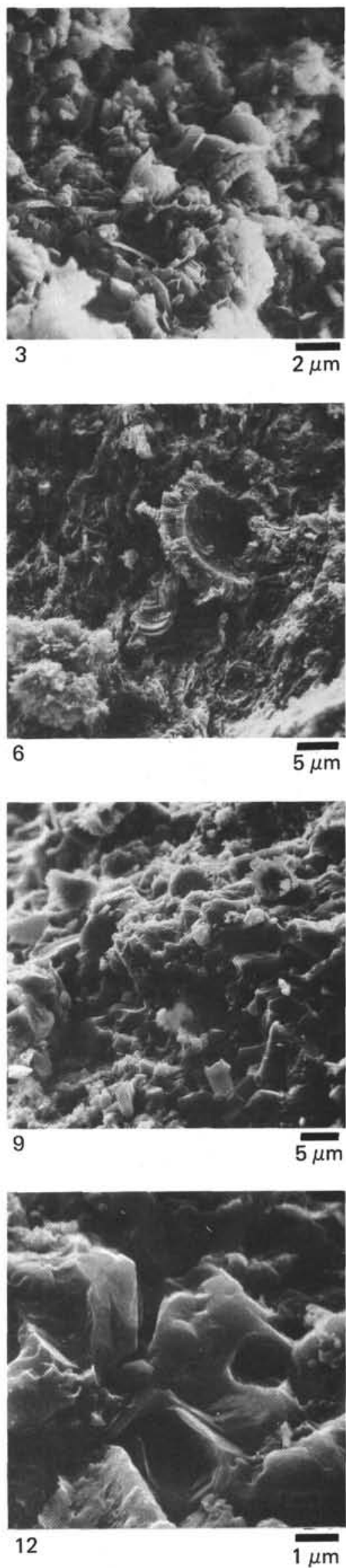
PLATE 2

(All figures are scanning electron micrographs.)

Figure 1 Sample 367-31-1, 65-67 cm (C2). Structure of chert nodule. Resembles view of "lepispheres" fig. 8b, Wise and Weaver (1974). Magnification $\times 1850$. Scale bar $=2 \mu \mathrm{m}$.

Figure 2 Sample 105-21-1, 62-63 cm. "Lepisphere" of cristobalite in fairly well preserved nanno-chalk (see also Plate 1, Figures 1 and 4: Plate 2, Figure 8). Magnification $\times 5600$. Scale bar $=1 \mu \mathrm{m}$.

Figure 3 Sample 105-38-2, 100-101 cm. Almost totally siliceous. Probably volcanic debris just above basalt. Magnification $\times 2475$. Scale bar $=2 \mu \mathrm{m}$.

Figure 4 Sample 367-34-4, 20-23 cm (W). "Wispy" appearance due to the presence of siliceous material ( $65 \%$ of sample). Authigenic calcite also common. Magnification $\times 2200$. Scale bar $=2 \mu \mathrm{m}$.

Figure 5 Sample $367-34-4,20-23 \mathrm{~cm}$ (W). High magnification view of Figure 12, sample as Figure 4. Shows "wispy" nature of silicate-rich sample. Magnification $\times 5500$. Scale bar $=1 \mu \mathrm{m}$.

Figure 6 Sample 105-21-1, 62-63 cm. Coccolith clearly showing development of overgrowths which would eventually totally obscure it. Note pressure solution on u-per edge of coccolith. Magnification $\times 11,200$. Scale bar $=0.5 \mu \mathrm{m}$.

Figure 7 Sample 105-21-1, 53-54 cm. Clay-rich sample. No microfossils recognizable in sample. Magnification $\times 1360$. Scale bar $=5 \mu \mathrm{m}$.

Figure 8 Sample 105-21-1, 62-63 cm. Carbonate-rich sample. Nannofossils abundant and moderately well preserved (see also Plate 1, Figures 1 and 4; Plate 2 , Figures 2 and 6 ). Magnification $\times 2250$. Scale bar $=2 \mu \mathrm{m}$.

Figure 9 Sample $367-35-4,51-53 \mathrm{~cm}$. Sample is only $6 \%$ carbonate, Jurassic in age, and buried over 1100 meters, yet this coccosphere is very well preserved. No overgrowths are observable. Magnification $\times 5700$. Scale bar $=1 \mu \mathrm{m}$.

Figure 10 Sample $367-34-4,61-63 \mathrm{~cm}$. Two nannofossils observable in center of the photo. Most of the sample appears to be authigenic. The sample is $88 \%$ calcite. Magnification $\times 2375$. Scale bar $=$ $2 \mu \mathrm{m}$.

Figure 11 Sample $367-34-4,20-23 \mathrm{~cm} \mathrm{\& R}$ ) Sample is $20 \%$ carbonate. No recognizable nannofossils. Magnification $\times 2150$. Scale bar $=2 \mu \mathrm{m}$.

Figure 12 Sample $367-34-4,20-23 \mathrm{~cm}(W)$. Sample is $35 \%$ carbonate. Most calcite appears authigenic but rare nannofossil fragments are present. Magnification $\times 2200$. Scale bar $=2 \mu \mathrm{m}$. 
PLATE 2
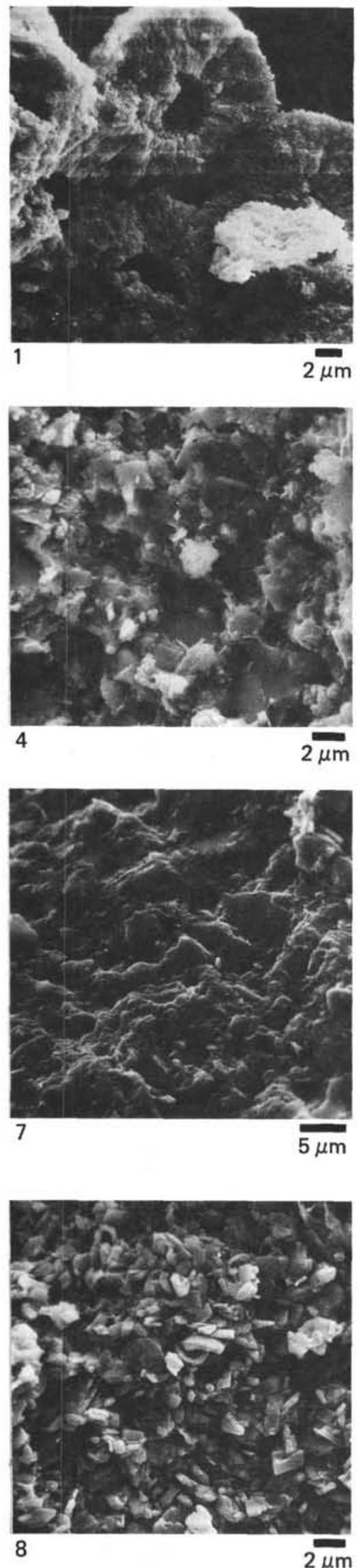
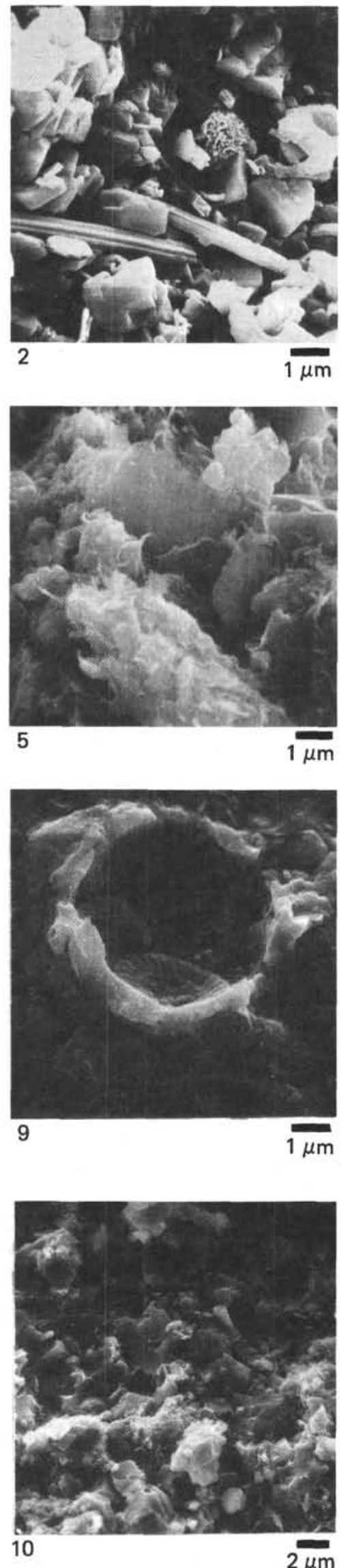
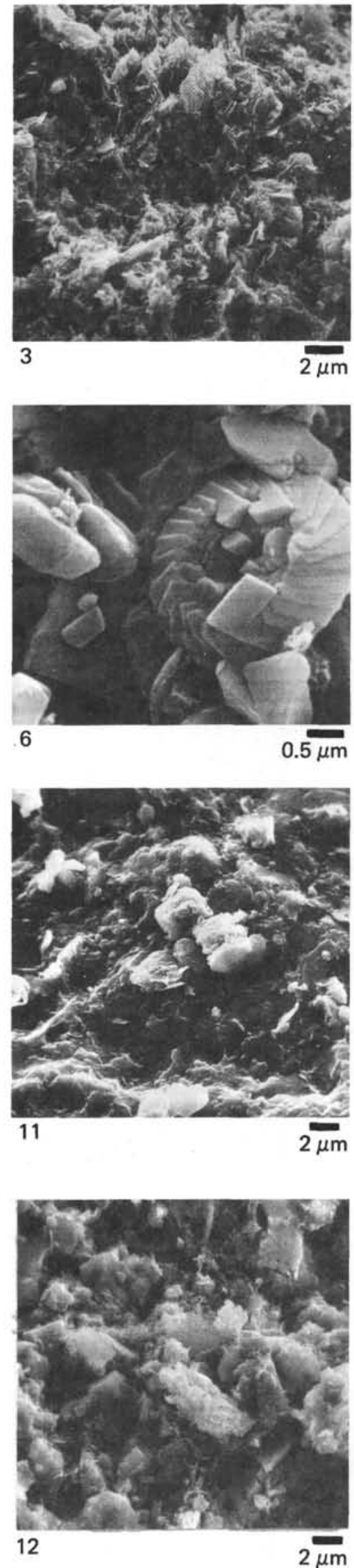